\title{
The Abnormalities of Adrenomedullary Hormonal System in Genetic Hypertension: Their Contribution to Altered Regulation of Blood Pressure
}

\author{
Anna VAVŘíNOVÁ ${ }^{1}$, Michal BEHULIAK ${ }^{1}$, Ivana VANĚČKOVÁ ${ }^{1}$, Josef ZICHA ${ }^{1}$ \\ ${ }^{1}$ Laboratory of Experimental Hypertension, Institute of Physiology of the Czech Academy of \\ Sciences, Prague, Czech Republic
}

Received March 24, 2021

Accepted April 22, 2021

Epub Ahead of Print May 12, 2021

\begin{abstract}
Summary
It is widely accepted that sympathetic nervous system plays a crucial role in the development of hypertension. On the other hand, the role of adrenal medulla (the adrenomedullary component of the sympathoadrenal system) in the development and maintenance of high blood pressure in man as well as in experimental models of hypertension is still controversial. Spontaneously hypertensive rats (SHR) are the most widely used animal model of human essential hypertension characterized by sympathetic hyperactivity. However, the persistence of moderately elevated blood pressure in SHR subjected to sympathectomy neonatally as well as the resistance of adult SHR to the treatment by sympatholytic drugs suggests that other factors (including enhanced activity of the adrenomedullary hormonal system) are involved in the pathogenesis of hypertension of SHR. This review describes abnormalities in adrenomedullary hormonal system of SHR rats starting with the hyperactivity of brain centers regulating sympathetic outflow, through the exaggerated activation of sympathoadrenal preganglionic neurons, to the local changes in chromaffin cells of adrenal medulla. All the above alterations might contribute to the enhanced release of epinephrine and/or norepinephrine from adrenal medulla. Special attention is paid to the alterations in the expression of genes involved in catecholamine biosynthesis, storage, release, reuptake, degradation and adrenergic receptors in chromaffin cells of SHR. The contribution of the adrenomedullary hormonal system to the development and maintenance of hypertension as well as its importance during stressful conditions is also discussed.
\end{abstract}

\section{Key words}

Adrenal gland • Chromaffin cells • Epinephrine • Blood pressure • Cardiovascular system $\bullet$ Stress

\section{Corresponding author}

A. Vavř́nová, Laboratory of Experimental Hypertension, Institute of Physiology of the Czech Academy of Sciences, Videnska 1083, CZ-142 20 Prague 4, Czech Republic. E-mail: anna.vavrinova@fgu.cas.cz

\section{Introduction}

The sympathetic nervous system (SNS) in cooperation with other humoral and local factors is involved in the regulation of arterial blood pressure (BP) through the changes of regional vascular resistance and/or cardiac output. SNS contribution varies under particular circumstances, such as postural changes, physical exercise, stress, etc. It is widely accepted that SNS plays a crucial role in the development of human hypertension (Fisher and Paton 2012) and various forms of experimental hypertension (Mancia and Grassi 2014). On the other hand, the role of adrenal medulla (the adrenomedullary component of the sympathoadrenal system) in the development and maintenance of high blood pressure in man as well as in experimental models is still controversial (Floras 1992, Elam and Grassi 2000). Spontaneously hypertensive rats (SHR) are the mostly used animal model of human essential hypertension (Yagil and Yagil 2001). They develop hypertension 
without any physiological, pharmacological or surgical intervention at the age of 5-12 weeks and their mean arterial pressure in adulthood achieves $160-180 \mathrm{~mm} \mathrm{Hg}$, which is in contrast to $110-130 \mathrm{~mm} \mathrm{Hg}$ in adult normotensive controls of Wistar-Kyoto (WKY) strain (Judy and Farrell 1979, Behuliak et al. 2015). Numerous functional and structural abnormalities were described in SHR including abnormal neurohumoral regulation, vascular hypertrophy, impaired endothelium-dependent relaxation, renal dysfunction, etc. (Zicha and Kunes 1999, Pintérová et al. 2011). The sympathetic nervous system is considered to be involved in the pathogenesis of hypertension in SHR since the sympathetic activity rises dramatically in parallel with BP development (Judy and Farrell 1979). Moreover, the development of hypertension in SHR can be substantially attenuated by neonatal sympathectomy (destruction of sympathetic nervous system, e.g. by guanethidine administration) (Lee et al. 1987, Korner et al. 1993) but this intervention is markedly less efficient in reducing BP in adult SHR (Yamori et al. 1972, Ferrari et al. 1991, Vavrínová et al. 2019b). The persistence of moderately elevated BP in SHR subjected to neonatal sympathectomy as well as the resistance of adult SHR to guanethidine treatment suggests that other factors are involved in the pathogenesis of hypertension in SHR, including the enhanced activity of the adrenomedullary system (Borkowski 1991, Lee et al. 1991a, Lee et al. 1991b). Indeed, some papers reported increased plasma levels of epinephrine and its metabolite metanephrine in SHR compared to normotensive WKY rats (Vlachakis et al. 1980, Szemeredi et al. 1988, Vavř́nová et al. 2019b). On the other hand, similar plasma levels of epinephrine and metanephrine were described by many other researchers (Szemeredi et al. 1988, Moura et al. 2005, Behuliak et al. 2018, Vavř́nová et al. 2019a). These discrepancies can be partly explained by the influence of stress during particular experimental conditions since the plasma levels of epinephrine are increased more in SHR than in WKY rats following stress (McCarty et al. 1978, Kvetnansky et al. 1979). This review deals with numerous abnormalities in the adrenomedullary system described in SHR with established hypertension as well as before the development of high blood pressure (Kumai et al. 1994, Miranda-Ferreira et al. 2008, Vavřínová et al. 2019a). This approach might help to distinguish the abnormalities that are rather the consequences of high blood pressure from those that can play a decisive role in the pathophysiology of hypertension in SHR.

\section{The functional organization of the adreno- medullary system}

In general, the autonomic nervous system (sympathoadrenal and parasympathetic branch) is regulated by a complex central neural network (e.g. nucleus of the solitary tract, NTS; paraventricular nucleus of hypothalamus, PVN; rostral ventrolateral medulla, RVLM; nucleus ambiguous, NA etc.), which control the activity of particular efferent preganglionic neurons innervating either sympathetic postganglionic neurons, adrenal medulla or parasympathetic postganglionic neurons. The sympathetic and parasympathetic postganglionic neurons form synapses with target tissues (e.g. vascular smooth muscle cells, cardiac conduction system, etc.), whereas the chromaffin cells of adrenal medulla release catecholamines into the blood stream thus influencing the distant tissues in the organism. The regulation of sympathoadrenal and parasympathetic nervous system is complex and exerts reciprocal interactions of both systems at the level of PVN, RVLM, preganglionic neurons as well as at the level of postganglionic neurons and target tissues allowing the precise regulation of organ and tissue functions (Ondicova and Mravec 2010). Considering the adrenomedullary system, the evidence indicates that there are two separate populations of chromaffin cells releasing either epinephrine or norepinephrine, which are regulated by distinct neural pathways allowing the differential secretion according to the physiological demands of the organism (Flatmark 2000, de Diego et al. 2008). Thus, there is a high norepinephrine release by adrenal medulla during cold exposure (although the major part of norepinephrine during cold exposure is released by sympathetic nerve endings), whereas high epinephrine release was found during hypoglycemia (Khalil et al. 1986, Vollmer et al. 1992).

Transneuronal retrograde cell-body labeling technique demonstrated that there are at least 5 brain areas directly involved in the regulation of efferent sympathoadrenal preganglionic neurons: caudal raphe nuclei, ventromedial medulla, rostral ventrolateral medulla (RVLM), A5 cell group, and paraventricular nucleus of hypothalamus (PVN) (Strack et al. 1989). RVLM is one of the most important central regions involved in cardiovascular regulation, which integrates the information coming from various peripheral receptors (vestibular receptors, skeletal muscle receptors, nociceptors etc.), nucleus of the solitary tract (mediating 
baroreceptor and chemoreceptor reflexes), PVN (involved in the regulation of body fluids, metabolism and temperature) and higher brain regions. RVLM is also a crucial structure for the baroreflex regulation which determines both sympathoadrenal and sympathoneural outflow (Guyenet 2006, Dampney 2016). Anterograde and retrograde tracing method demonstrated that neurons projecting to sympathoadrenal preganglionic neurons are concentrated in the more rostral part of the rat RVLM and less at the caudal level of the nucleus (Zagon and Smith 1993, Pyner and Coote 1998). In contrast, the neurons projecting to cervical preganglionic neurons are more dispersed from rostral to caudal levels of the RVLM nucleus (Pyner and Coote 1998). However, a doublevirus transneuronal labeling technique revealed that some RVLM neurons are involved in the regulation of both sympathoneural and sympathoadrenal outflow, which probably work under certain circumstances where parallel sympathetic activation is desirable, such as during the fight-or-flight response (Jansen et al. 1995). Physiological studies in cats revealed the existence of the RVLM territories the stimulation of which could preferably activate particular sympathetic outflows regulating different functions of the organism, e.g. muscle vasoconstriction, visceral vasoconstriction and kidney function (McAllen and May 1994). However, no functional experiments differentiating RVLM areas involved in the regulation of either sympathoneural or sympathoadrenal outflows in the rat were published so far. In RVLM of SHR, immunohistochemical staining demonstrated increased basal number of Fos-positive immunoreactive neurons compared to WKY rats (Minson et al. 1996, Palmer and Printz 1999). On the other hand, the BP reduction after the administration of NO donor sodium nitroprusside increased a number of Fos-positive immunoreactive RVLM neurons in WKY rats but not in SHR (Minson et al. 1996). Similarly, a psychological stimulus (airpuff startle) caused lower activation of RVLM neurons in SHR than in WKY rats (2-fold or 4-fold increase, respectively) (Palmer and Printz 1999). A faster firing rate was described in RVLM and PVN neurons of SHR compared to WKY rats (Matsuura et al. 2002, Li et al. 2008, Stern et al. 2012) which is in line with the above mentioned increased basal Fos immunoreactivity. Moreover, the hyperpolarization of RVLM and PVN neurons (induced by the microinjection of a viral vector coding for human inward-rectifier Kir2.1-potassium channel) resulted in the reduction of sympathetic outflow and BP decrease in SHR (Geraldes et al. 2014, Geraldes et al. 2016). Thus, it is clear that the hyperactivity of the brain centers regulating sympathetic outflow contribute to high BP in SHR but a more detailed information concerning the regulation of sympathoneural and sympathoadrenal outflows would be desirable.

The cell bodies of sympathoadrenal preganglionic neurons are located in the intermediolateral cell column between the first and the thirteenth thoracic segments (Zagon et al. 1993, Pyner and Coote 1994, Pyner and Coote 1998, Mueller et al. 2011). Sympathoadrenal preganglionic neurons occupy the lateral aspect of the intermediolateral cell column, whereas preganglionic neurons projecting to superior cervical ganglion and stellate ganglion are located more medially or centrally, respectively (Pyner and Coote 1994). The axons of the sympathoadrenal preganglionic neurons arise from the sympathetic trunk as the splanchnic nerves and form the synapses with chromaffin cells of adrenal medulla (Mueller et al. 2011). It was proposed that there are two distinct populations of sympathoadrenal preganglionic neurons differing in their sensitivity to various stimuli and also in their conduction velocity. Morrison et al. (2000) demonstrated that the first group comprised slowly conducting preganglionic neurons. These neurons were markedly excited during the pseudo-hypoglycemia induced by 2-deoxy-D-glucose, but they exhibited little or no sensitivity to the baroreceptor reflex activation. They probably innervate epinephrineproducing chromaffin cells. By contrast, the second group of sympathoadrenal preganglionic neurons showed rapid conduction velocity similar to barosensitive vasoconstrictor sympathetic preganglionic neurons. These neurons were unaffected by pseudo-hypoglycemia, but they were highly sensitive to baroreceptor reflex activation. They likely regulate norepinephrine release from the adrenal medulla (Morrison et al. 2000). This suggests that norepinephrine-producing chromaffin cells of adrenal medulla might be regulated in concert with sympathetic neurons innervating blood vessels. In the spinal cord of SHR, there is a greater basal incidence of Fos-positive sympathoadrenal preganglionic neurons compared to WKY rats (Minson et al. 1996), which is in accordance with the increased constitutive activity of the splanchnic nerves in this hypertensive strain (Morrison and Whitehorn 1984, Ricksten et al. 1984). Moreover, a greater number of sympathoadrenal preganglionic neurons was activated by nitroprusside administration in SHR (Minson et al. 1996) and the enhanced response to hypothalamic stimulation was described in splanchnic 
nerves of SHR compared to WKY rats (Takeda and Buñag 1978, Morrison and Whitehorn 1984). Furthermore, SHR exhibited more pronounced activation of sympathoadrenal preganglionic fibers to various stimuli, including ganglionic blockade by trimethaphan, mental stress caused by air-jet and pseudo-hypoglycemia induced by 2-deoxy-D-glucose when compared to normotensive WKY rats (Zhang and Thorén 1998). The enhanced activation of preganglionic neurons observed after various stimuli in SHR is not associated with the augmented activation of RVLM neurons (see above) and the contribution of other brain areas remains to be elucidated. However, excitatory stimulation elicited greater adrenal nerve responses in anesthetized spinally transected SHR compared to WKY rats (Schramm and Chornoboy 1982). Taken together, the hyperexcitability of sympathoadrenal preganglionic neurons in SHR seems to be at least partially independent of the central influence. This abnormality contributes to the greater stress-induced catecholamine release by adrenal medulla in SHR and potentially participates in hypertension development.

The main physiological stimulus for catecholamine secretion from adrenal medulla is acetylcholine (released by preganglionic neurons) which induces depolarization of chromaffin cells and subsequent increase in their intracellular calcium (Burgoyne 1991). Catecholamine release is modulated by substances such as neuropeptide Y, angiotensin II, substance P, cholecystokinin or adrenocorticotropic hormone (Mravec 2005, Guérineau 2020). It was hypothesized that adrenal medulla might play a role as a sensory organ and thus the non-cholinergic stimulation of chromaffin cells might participate in more complex regulation of catecholamine release (Mravec 2005). Catecholamine release evoked by the stimulation of cholinergic receptors as well as the membrane depolarization was described to be augmented in perfused adrenal glands of SHR in comparison to those of WKY rats (Lim et al. 2002, Bomfim et al. 2017). This was caused by both enhanced calcium signaling (de Pascual et al. 2013) and faster exocytosis of more vesicles as well as by greater quantal catecholamine content in hypertensive rats (Miranda-Ferreira et al. 2008). Moreover, the adrenal medulla of SHR contains a greater area of the norepinephrine releasing cell islets. Moreover, the increased number of both norepinephrine granules and vesicles was demonstrated in SHR from the prehypertensive stage to adulthood as compared to
WKY rats (Tabei et al. 1988). Thus, the local alterations of catecholamine biosynthesis, storage, release, reuptake and degradation in chromaffin cells might also contribute to the enhanced release of epinephrine and/or norepinephrine from adrenal medulla in hypertensive rats. These aspects will be discussed in detail in the following parts of this review.

\section{Catecholamine biosynthesis}

The scheme of catecholamine biosynthesis, storage, release, reuptake and degradation in chromaffin cells is shown in the Figure 1. The catecholamine biosynthesis starts with an import of amino acid L-tyrosine and its hydroxylation by the enzyme tyrosine hydroxylase (TH, encoded by $T h$ gene; Nagatsu et al. 1964). For catecholamine biosynthesis, TH enzyme requires $\mathrm{Fe}^{2+}$, molecular oxygen and the regulatory cofactor tetrahydrobiopterin (Nagatsu et al. 1964) which is synthesized by guanosine triphosphate cyclohydrolase 1 (encoded by Gchl gene) and recycled by quinoid dihydropteridine reductase (encoded by $Q d p r$ gene; Thöny et al. 2000). Tyrosine hydroxylation is a ratelimiting step of catecholamine synthesis and it is a subject of complex regulation, including direct inhibition of the enzyme by catecholamines, posttranslational modifications and changes in the transcription of $T h$ gene (for review see Tekin et al. 2014). The second enzyme involved in catecholamine synthesis is L-DOPA decarboxylase (DDC, encoded by $D d c$ gene) which converts L-DOPA to dopamine (Blaschko 1942). Subsequently, dopamine is converted by the enzyme dopamine $\beta$-hydroxylase (DBH, encoded by $D b h$ gene) to form norepinephrine (Friedman and Kaufman 1965). The last enzyme phenylethanolamine N-methyl transferase (PNMT, encoded by Pnmt gene), which synthesizes epinephrine from norepinephrine, can be predominantly found in chromaffin cells of adrenal medulla, whereas extra-adrenal PNMT is expressed in a small number of epinephrine-producing neurons in the central nervous system and in some non-neuronal cells of the heart. Morphological studies showing the greatest expression of PNMT and/or epinephrine in the peripheral portion of the medulla, closest to the cortex, suggest that glucocorticoids are critical for efficient epinephrine synthesis in the chromaffin cells (Wong et al. 1987, Wong et al. 2003). It was shown that the expression and activity of catecholamine biosynthetic enzymes in chromaffin cells is regulated in a stimulus-specific 
manner by several mechanisms including acetylcholine (released from sympathetic innervation), glucocorticoids and Ang II (Livett and Marley 1993, Stachowiak et al. 1990, Wong 2006). Other experiments using a combination of stress with various interventions (including hypophysectomy, preganglionic denervation of sympathetic nerves or the adrenal medulla, treatment with hormones or neural agents, e.g. ACTH, glucocorticoid, acetylcholine etc.) further suggest that the induction of Th gene may be primarily mediated by the neural activity, whereas the regulation of Pnmt gene is dependent mainly on hormonal influences (Axelrod and Reisine 1984, Viskupic et al. 1994).

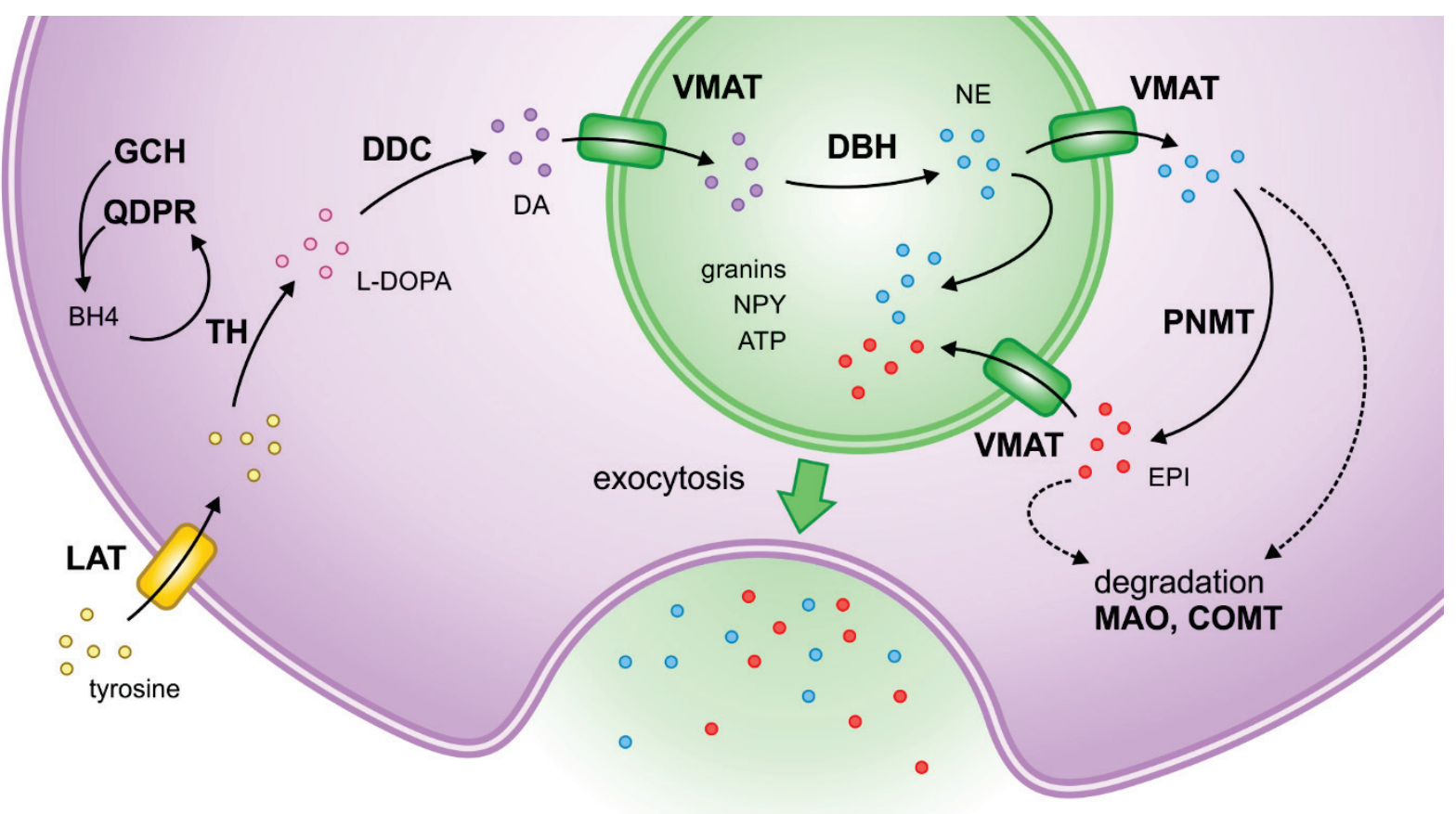

Fig. 1. The scheme of catecholamine biosynthesis, storage, release and degradation in chromaffin cells of the adrenal medulla. The amino acid L-tyrosine is imported into the cytoplasm of chromaffin cells by L-type amino acid transporter (LAT) and converted to L-3,4-dihydroxyphenylalanine (L-DOPA) by the enzyme tyrosine hydroxylase (TH). TH requires the regulatory cofactor tetrahydrobiopterin (BH4) which is synthesized by guanosine triphosphate cyclohydrolase (GCH) and recycled by quinoid dihydropteridine reductase (QDPR). L-DOPA is converted by L-DOPA decarboxylase (DDC) to form dopamine (DA). DA is transported to the chromaffin vesicles by the vesicular monoamine transporter (VMAT). The enzyme dopamine $\beta$-hydroxylase (DBH) catalyzes DA conversion to norepinephrine (NE). The final step of biosynthesis is performed in the cytoplasm by phenylethanolamine $\mathrm{N}$-methyl transferase (PNMT) which synthesizes epinephrine (EPI) from NE. The content of chromaffin vesicles (NE, EPI, granins, neuropeptide $Y$ (NPY) and ATP) is released from the cells by the process of exocytosis. Monoamine oxidases (MAO) and catechol-O-methyltransferase (COMT) remove catecholamines from the cytoplasm (after vesicular leakage).

Many studies have been published concerning the catecholamine biosynthesis in the adrenal glands of SHR with established hypertension, but their results are quite contradictory (see Table 1). The mRNA and protein expression of Th and Pnmt genes in the adrenal gland of adult SHR was reported to be higher (Kumai et al. 1994, Reja et al. 2002a, Reja et al. 2002b, Nguyen et al. 2009) or lower than in adrenals of WKY rats (Moura et al. 2005, Grundt et al. 2009, Vavř́nová et al. 2019a). Moreover, we observed the downregulated adrenal expression of other enzymes involved in catecholamine biosynthesis ( $D d c$ and $D b h)$ as well as the enzymes producing cofactor tetrahydrobiopterin (Gch1, Qdpr) for TH in adult SHR compared to WKY rats (Vavřínová et al. 2019a). The studies concerning adrenal content of dopamine, norepinephrine and epinephrine also provided rather conflicting results (Lee et al. 1991a, Korner et al. 1993, Moura et al. 2005, Vavř́nová et al. 2019a, Vavř́nová et al. 2019b). The inconsistent results might be caused by extreme susceptibility of the catecholaminergic system to stressful conditions and the differences in stress response between SHR and WKY rats. It is well known that acute stress elevates plasma levels of catecholamines and induces the 
Table 1. The overview of papers evaluating the adrenal mRNA expression, protein expression and the enzyme activity of genes involved in catecholamine biosynthesis in spontaneously hypertensive rats (SHR). Gene symbols referring to mRNA expression are italicized, whereas all letters are in upper-case when describing protein expression or enzyme activity. The information about anesthesia, euthanasia and other important factors can be found in a note section. Symbols $\downarrow$, $\uparrow$ and $=$ represent lower, higher or similar expression in SHR, respectively, compared to Wistar-Kyoto controls, if not stated otherwise. AG, adrenal gland; AM, adrenal medulla; IP, intraperitoneal; qPCR, quantitative real-time PCR; sqPCR, semiquantitative real-time PCR; w, weeks; WB, western-blot.

\begin{tabular}{|c|c|c|c|c|c|c|}
\hline Reference & Age & $\begin{array}{c}\text { Parameter } \\
\text { (method) }\end{array}$ & Tissue & Gene change in SHR & & Note \\
\hline \multirow{2}{*}{$\begin{array}{l}\text { Friese et al. } \\
2005\end{array}$} & $4 w$ & mRNA (chip) & $\mathrm{AG}$ & Dbh, Pnmt & $\downarrow$ & Anesthesia not specified \\
\hline & & & & Th, Gchl & $=$ & Euthanasia not specified \\
\hline \multirow{6}{*}{$\begin{array}{l}\text { Grobecker et } \\
\text { al. } 1982\end{array}$} & $2 \mathrm{w}$ & Enzyme activity & $\mathrm{AG}$ & TH, DBH, PNMT & $\downarrow$ & Tail-cuff (timepoint not specified) \\
\hline & $4 w$ & & & TH, DBH, PNMT & $\downarrow$ & Decapitation \\
\hline & $8 \mathrm{w}$ & & & $\mathrm{TH}$ & $=$ & \\
\hline & & & & DBH, PNMT & $\downarrow$ & \\
\hline & $14 w$ & & & $\mathrm{TH}$ & $\uparrow$ & \\
\hline & & & & DBH, PNMT & $=$ & \\
\hline \multirow{2}{*}{$\begin{array}{l}\text { Grundt et al. } \\
2009\end{array}$} & $20 w$ & mRNA (qPCR) & $\mathrm{AG}$ & $T h$ & $\downarrow$ & Stress-naive \\
\hline & & & & & & Decapitation \\
\hline \multirow{2}{*}{$\begin{array}{l}\text { Grundt et al. } \\
2009\end{array}$} & $20 \mathrm{w}$ & mRNA (qPCR) & AG & $T h$ & $=$ & Immediately after tail-cuff \\
\hline & & & & & & Decapitation \\
\hline \multirow{2}{*}{$\begin{array}{l}\text { Jirout et al. } \\
2010\end{array}$} & $6 w$ & mRNA (chip) & AG & $T h, D d c, D b h$ & $\downarrow$ & Brown-Norway control \\
\hline & & & & Pnmt, Gch1, Qdpr & $=$ & Cervical dislocation \\
\hline \multirow{3}{*}{$\begin{array}{l}\text { Kumai et al. } \\
1994\end{array}$} & $25 \mathrm{w}$ & mRNA & $\mathrm{AM}$ & $T h$ & $\uparrow$ & Tail-cuff (timepoint not specified) \\
\hline & & (Northern blot) & & & & Anesthesia not specified \\
\hline & & Enzyme activity & & $\mathrm{TH}$ & $\uparrow$ & Euthanasia not specified \\
\hline \multirow{3}{*}{$\begin{array}{l}\text { Kumai et al. } \\
2001\end{array}$} & $15 \mathrm{w}$ & Protein $(\mathrm{WB})$ & & $\mathrm{TH}$ & $\uparrow$ & Tail-cuff (timepoint not specified) \\
\hline & & Enzyme activity & & $\mathrm{TH}$ & $\uparrow$ & Pentobarbital anesthesia \\
\hline & & & & & & Decapitation \\
\hline \multirow{6}{*}{$\begin{array}{l}\text { Moura et al. } \\
2005\end{array}$} & $5 w$ & Protein (WB) & AG & $\mathrm{TH}$ & $\downarrow$ & Tail-cuff (timepoint not specified) \\
\hline & & Enzyme activity & & $\mathrm{TH}$ & $\downarrow$ & Sodium pentobarbital \\
\hline & $12 \mathrm{w}$ & Protein (WB) & & $\mathrm{TH}$ & $\downarrow$ & \\
\hline & & Enzyme activity & & $\mathrm{TH}$ & $\downarrow$ & \\
\hline & $22 \mathrm{w}$ & Protein (WB) & & $\mathrm{TH}$ & $\downarrow$ & \\
\hline & & Enzyme activity & & $\mathrm{TH}$ & $\downarrow$ & \\
\hline $\begin{array}{l}\text { Nagatsu et } \\
\text { al. } 1976\end{array}$ & $3 w$ & Enzyme activity & AG & $\mathrm{DBH}$ & $\uparrow$ & Decapitation \\
\hline \multirow{2}{*}{$\begin{array}{l}\text { Nagatsu et } \\
\text { al. } 1977\end{array}$} & $16 \mathrm{w}$ & Enzyme activity & AG & $\mathrm{TH}, \mathrm{DBH}$ & $\uparrow$ & Tail-cuff (timepoint not specified) \\
\hline & & & & & & Decapitation \\
\hline \multirow{3}{*}{$\begin{array}{l}\text { Nguyen et } \\
\text { al. } 2009\end{array}$} & $16 \mathrm{w}$ & mRNA (sqPCR) & $\mathrm{AG}$ & $D b h$ & $=$ & Repeated tail-cuff \\
\hline & & Protein (WB) & & Th, Pnmt & $\uparrow$ & Ketamine-xylazine anesthesia \\
\hline & & & & PNMT & $\uparrow$ & Decapitation \\
\hline \multirow{3}{*}{$\begin{array}{l}\text { O'Connor et } \\
\text { al. (1999) }\end{array}$} & $20-$ & Enzyme activity & AG & $\mathrm{DBH}$ & $\downarrow$ & Tail-cuff (timepoint not specified) \\
\hline & $24 w$ & & & PNMT & $=$ & Anesthesia not specified \\
\hline & & & & & & Euthanasia not specified \\
\hline \multirow{2}{*}{$\begin{array}{l}\text { Reja et al. } \\
2002 \mathrm{a}\end{array}$} & $18 w$ & mRNA (qPCR) & $\mathrm{AM}$ & $T h$ & $\uparrow$ & Tail-cuff 2 weeks before sampling \\
\hline & & & & & & $\begin{array}{c}\text { Euthanasia by sodium } \\
\text { pentobarbitone IP }\end{array}$ \\
\hline \multirow{2}{*}{$\begin{array}{l}\text { Reja et al. } \\
2002 \mathrm{~b}\end{array}$} & $20 w$ & mRNA (qPCR) & $\mathrm{AM}$ & Pnmt & $\uparrow$ & Tail-cuff 2 weeks before sampling \\
\hline & & & & & & $\begin{array}{l}\text { Euthanasia by sodium } \\
\text { pentobarbitone IP }\end{array}$ \\
\hline
\end{tabular}




\begin{tabular}{|c|c|c|c|c|c|c|}
\hline \multirow[t]{4}{*}{$\begin{array}{l}\text { Vavřínová et } \\
\text { al. 2019a }\end{array}$} & $4 w$ & mRNA (qPCR) & $\mathrm{AM}$ & $\begin{array}{c}\text { Dbh, Pnmt } \\
\text { Th, Ddc, Qdpr } \\
\text { Gch1 }\end{array}$ & $\begin{array}{l}\downarrow \\
= \\
\uparrow\end{array}$ & $\begin{array}{c}\text { Isoflurane } \\
\text { Exsanguination }\end{array}$ \\
\hline & & Protein (WB) & $\mathrm{AG}$ & $\begin{array}{l}\text { DDC, DBH } \\
\text { TH, PNMT }\end{array}$ & $\begin{array}{l}\downarrow \\
=\end{array}$ & \\
\hline & $24 w$ & mRNA (qPCR) & $\mathrm{AM}$ & $\begin{array}{c}\text { Th, Ddc, Dbh, Pnmt, } \\
\text { Qdpr, Gchl }\end{array}$ & $\begin{array}{l}\downarrow \\
\downarrow\end{array}$ & \\
\hline & & Protein (WB) & $\mathrm{AG}$ & $\begin{array}{c}\text { TH, DDC, DBH } \\
\text { PNMT }\end{array}$ & $\begin{array}{l}\downarrow \\
=\end{array}$ & \\
\hline $\begin{array}{l}\text { Vavřínová et } \\
\text { al. } 2019 \mathrm{~b}\end{array}$ & $\begin{array}{l}22- \\
24 w\end{array}$ & mRNA (qPCR) & $\mathrm{AM}$ & $\begin{array}{c}\text { Th } \\
D d c, \text { Dbh, Pnmt }\end{array}$ & $\downarrow$ & $\begin{array}{c}\text { Daily IP injection of saline for } \\
2 \text { weeks } \\
\text { Isoflurane } \\
\text { Exsanguination }\end{array}$ \\
\hline
\end{tabular}

expression of catecholamine biosynthetic enzymes in adrenal medulla (Kvetnansky et al. 2004, Kvetnansky et al. 2009). By contrast, the chronic stress induced by social isolation decreases basal expression of $T h$ gene (Gavrilovic et al. 2008), but chronically stressed animals exhibit higher plasma epinephrine levels and the augmented induction of adrenal Th expression when exposed to a novel stressor (McCarty et al. 1988, Gavrilovic et al. 2008). Adult SHR acutely exposed to immobilization show higher plasma levels of norepinephrine and epinephrine compared to WKY rats (Kvetnansky et al. 1979). Moreover, the increase in adrenal mRNA expression of $T h$, induced by $25 \mathrm{~min}$ of mild stress due to tail cuff measurement of blood pressure, was found to be greater in adult SHR compared to WKY rats (Grundt et al. 2009). These findings are in agreement with the above mentioned exaggerated activation of sympathoadrenal preganglionic fibers observed in SHR subjected to physical or psychological stressors (Zhang and Thorén 1998). Actually, several research groups, which reported on the hyperactivation of the adrenomedullary system in SHR, exposed the rats acutely or repeatedly to the stressful procedures such as tail-cuff BP measurement or repeated intraperitoneal administration of drugs (Korner et al. 1993, Kumai et al. 1994, Nguyen et al. 2009). It should be realized that the use of various types of anesthesia (sodium pentobarbital, ketamine-xylazine, isoflurane, etc.) as well as methods of anesthesia (decapitation, cervical dislocation, overdose by anesthetics, etc.) might influence the results, but the details concerning these procedures are often not included in the papers (see notes in Table 1). Besides the differences in the adrenomedullary system, SHR exhibited many other signs of their vulnerability to stress, including higher stress-induced plasma corticosterone levels (Kvetnansky et al. 1979) or ACTH levels (Behuliak and Vavřínová unpublished data). Furthermore, adult stress-naive SHR showed adrenal hypertrophy, increased locomotion (Vavřínová et al. 2019a, Vavřínová et al. 2019b), hyperthermia (Hajós and Endberg 1986) and thymic atrophy (Suzuki et al. 1999), that might be considered as the hallmarks of adaptation to chronic stress (Ulrich-Lai et al. 2006). Brown et al. (1988) demonstrated that intracerebroventricular administration of corticotropin-releasing hormone $(\mathrm{CRH})$ produced a greater increase of plasma epinephrine in SHR suggesting that the central stress pathways might trigger the augmented activation of the adrenomedullary system in this rat strain.

The adrenomedullary system might be prone to the greater activation already in the prehypertensive stage. Similar to adult SHR, catecholamine biosynthetic pathway was described to be downregulated, unchanged or upregulated in adrenal gland of 4-week-old prehypertensive SHR compared to WKY rats (Grobecker et al. 1976, Nagatsu et al. 1976, Friese et al. 2005, Moura et al. 2005, Vavř́nová et al. 2019a). Accordingly, the increased cardiac index and heart rate was observed in conscious partially restrained 4-week-old SHR compared to WKY rats (Smith and Hutchins 1979, Behuliak et al. 2015, Vavř́nová et al. 2019a). It seems that the central stress pathways are hyperresponsive in prehypertensive SHR because the exaggerated $\mathrm{CRH}$-induced ACTH response and higher corticosterone levels were described in this strain already at the age of 5-6 weeks (Hattori et al. 1986, Hashimoto et al. 1989, Sterley et al. 2011). Indeed, the acute central administration of tranquilizing agent muscimol (GABA type $\mathrm{A}$ receptor agonist) reduced sympathoadrenal activity, lumbar sympathetic nerve activity and BP, the effects being more pronounced in 
SHR than in WKY rats (Unger et al. 1984, Allen 2002). Moreover, chronic treatment with tranquilizing drug diazepam (positive allosteric modulator of the GABA type A receptors) given from the newborn period markedly reduced BP and vascular resistance in SHR to the levels only slightly above those found in WKY rats (Schieken 1979). Thus, the genetic predisposition of SHR might determine their vulnerability to stress and these rats probably perceive usual care and handling as more stressful. This state of chronic stress can contribute to the above mentioned alterations of the adrenomedullary system in SHR (the decreased basal expression of catecholamine biosynthetic enzymes but the pronounced induction of the expression and the augmented catecholamine release under stress conditions). The alternative explanation is that the downregulation of catecholamine biosynthetic pathway might be a consequence of the high blood pressure, e.g. a compensatory mechanism counteracting the hyperactivity of sympathoneural system in SHR. Indeed, SHR with transgenically overexpressed $D b h$ gene exhibited higher plasma levels of epinephrine and norepinephrine as well as higher blood pressure compared to non-transgenic SHR controls (Pravenec et al. 2016). Guanethidine-induced sympathectomy for 14 days increased the mRNA expression of Th, Dbh and Pnmt genes in adrenal medulla and elevated plasma levels of epinephrine of adult SHR and WKY rats. However, these effects were more pronounced in WKY rats than in SHR, which does not support the idea that the sympathetic hyperactivity is a cause of the downregulation of catecholamine biosynthetic pathway in SHR (Vavř́nová et al. 2019b).

Taken together, the available evidence indicates that the catecholamine biosynthetic pathway is downregulated at different levels, i.e. mRNA expression, protein expression and the catecholamine content in the adrenal glands of stress-naive SHR with established hypertension when compared to WKY rats. However, the acute or chronic stressful stimuli cause a more pronounced activation of the adrenomedullary system in SHR, which should be taken into account during the design of experiments and also during the interpretation of results.

\section{Catecholamine vesicles}

The speed and the effectiveness of catecholamine release from the chromaffin cells of adrenal medulla depend on the immediate availability of vesicles filled with high content of catecholamines. The filling of catecholaminergic vesicles is mediated by vesicular monoamine transporters (VMAT) of two types (Blakely and Edwards 2012). Colocalization study showed that VMAT1 (encoded by Slc18al gene) is widely expressed in all rat adrenal chromaffin cells, while VMAT2 (Slc18a2 gene) is co-localized with TH but not with PNMT enzyme (Tillinger et al. 2010). This suggests that VMAT2 is expressed in norepinephrine- but not in epinephrine-synthesizing chromaffin cells. The mRNA expression of both Vmat1 and Vmat2 was reported to be decreased in adrenal medulla of adult SHR compared to WKY rats (Vavř́nová et al. 2019a). The literature concerning expression of Vmat genes (and other genes related to catecholamine vesicles, reuptake or degradation which are discussed hereafter) in adrenal gland of SHR is summarized in Table 2. Our research group reported unchanged mRNA expression of Vmat1 and lower expression of Vmat2 in adrenal gland of prehypertensive SHR (Vavř́nová et al. 2019a), whereas Friese et al. (2005) demonstrated the attenuated expression of Vmat1 and the augmented expression of Vmat2. The inconsistent results might be caused either by different methods of measurement (quantitative real-time PCR vs. microarray analysis) or by different sampling of tissue (adrenal medulla vs. whole adrenal gland). It would be desirable to verify the expression of Vmat2 in prehypertensive SHR since the augmented expression of this gene might be a sign of the transition of adrenal chromaffin cells from epinephrine-producing to norepinephrine-producing phenotype.

Catecholamine storage vesicles of the adrenal medulla contain remarkably high concentrations of chromogranins (encoded by Chga and Chgb genes), secretogranin ( $\mathrm{Scg} 2$ gene), neuropeptide Y (Npy gene) and adenosine triphosphate (ATP). These molecules might influence the amount of catecholamines ready for exocytosis or when released they can mediate feedback regulation of catecholamine release from chromaffin cells (Burnstock 2014). Granins stabilize the vesicle core osmotically and they are involved in the regulation of exocytosis (Zhang et al. 2011). Chga knockout mice had the decreased size and number of chromaffin granules as well as the reduced adrenal content of epinephrine and norepinephrine (Mahapatra et al. 2005). In the adrenal medulla of prehypertensive SHR, the mRNA expression of Chga, Chgb and Scg2 was similar or slightly decreased compared to WKY rats (Friese et al. 2005, Vavř́nová et al. 2019a). We reported the attenuated mRNA 
expression of Chga, Chgb and Scg2 genes in the adrenal medulla of adult SHR (Vavřínová et al. 2019a), whereas the increased mRNA and protein expression of Chga was shown in the adrenal medulla of adult SHR by O'Connor et al. (1999) and Nguyen et al. (2009). Nevertheless, the latter two studies used the repeated tail-cuff measurement of BP, which might influence the results of these studies. Thus, similarly with the genes involved in the catecholamine biosynthesis, the basal expression of granins seems to be downregulated in adrenal medulla of SHR, but the expression might be activated by stressful conditions such as tail-cuff measurement use.

Table 2. The overview of papers evaluating the adrenal mRNA expression, protein expression and the enzyme activity of genes related to catecholamine vesicles, reuptake or degradation in spontaneously hypertensive rats (SHR). Gene symbols referring to mRNA expression are italicized, whereas all letters are in upper-case when describing protein expression or enzyme activity. The information about anesthesia, euthanasia and other important factors can be found in a note section. Symbols $\downarrow$, $\uparrow$ and $=$ represent lower, higher or similar expression in SHR, respectively, compared to Wistar-Kyoto controls, if not stated otherwise. AG, adrenal gland; AM, adrenal medulla; IP, intraperitoneal; NB, northern blot; qPCR, quantitative real-time PCR; RIA, radioimmunoassay; sqPCR, semiquantitative realtime PCR; w, weeks; WB, western-blot.

\begin{tabular}{|c|c|c|c|c|c|c|}
\hline Reference & Age & $\begin{array}{l}\text { Parameter } \\
\text { (method) }\end{array}$ & Tissue & Gene change in SHR & & Note \\
\hline \multirow{3}{*}{$\begin{array}{l}\text { Friese et al. } \\
2005\end{array}$} & \multirow[t]{3}{*}{$4 \mathrm{w}$} & \multirow[t]{3}{*}{ mRNA (chip) } & \multirow[t]{3}{*}{ AG } & Vmat1, Scg2, Maob & $\downarrow$ & \multirow{3}{*}{$\begin{array}{l}\text { Anesthesia not specified } \\
\text { Euthanasia not specified }\end{array}$} \\
\hline & & & & Chga, Chgb, Maoa, Net & $=$ & \\
\hline & & & & Vmat2, Comt & $\uparrow$ & \\
\hline $\begin{array}{l}\text { Guffroy and } \\
\text { Strollin } \\
\text { Benedetti } \\
1984\end{array}$ & $14-17 \mathrm{w}$ & Enzyme activity & AG & MAOA, MAOB & $=$ & Cervical dislocation \\
\hline \multirow{5}{*}{$\begin{array}{l}\text { Higuchi et } \\
\text { al. } 1993\end{array}$} & \multirow[t]{2}{*}{$6 w$} & mRNA (NB) & \multirow[t]{5}{*}{ AG } & Npy & $\downarrow$ & \multirow[t]{5}{*}{ Decapitation } \\
\hline & & Protein (RIA) & & NPY & $=$ & \\
\hline & \multirow[t]{2}{*}{$12 w$} & mRNA (NB) & & Npy & $\downarrow$ & \\
\hline & & Protein (RIA) & & NPY & $\uparrow$ & \\
\hline & $17 \mathrm{w}$ & mRNA (NB) & & Npy & $=$ & \\
\hline \multirow{2}{*}{$\begin{array}{l}\text { Jirout et al. } \\
2010\end{array}$} & \multirow[t]{2}{*}{$6 w$} & \multirow[t]{2}{*}{ mRNA (chip) } & \multirow[t]{2}{*}{$\mathrm{AG}$} & Npy, Comt & $\downarrow$ & \multirow{2}{*}{$\begin{array}{l}\text { Brown-Norway control } \\
\text { Cervical dislocation }\end{array}$} \\
\hline & & & & $\begin{array}{c}\text { Vmat1, Chga, Chgb, Scg2, } \\
\text { Maoa, Maob }\end{array}$ & $\begin{array}{l}= \\
=\end{array}$ & \\
\hline \multirow{3}{*}{$\begin{array}{l}\text { Nguyen et } \\
\text { al. } 2009\end{array}$} & \multirow[t]{3}{*}{$16 w$} & \multirow[t]{3}{*}{ mRNA (sqPCR) } & \multirow[t]{3}{*}{ AG } & \multirow[t]{3}{*}{ Chga } & \multirow[t]{3}{*}{$\uparrow$} & Repeated tail-cuff \\
\hline & & & & & & Ketamine-xylazine anesthesia \\
\hline & & & & & & Decapitation \\
\hline \multirow{3}{*}{$\begin{array}{l}\text { O'Connor et } \\
\text { al. (1999) }\end{array}$} & \multirow{3}{*}{$\begin{array}{c}4 w \\
20-24 w\end{array}$} & Protein (WB) & \multirow[t]{3}{*}{ AG } & CHGA & $\uparrow$ & Tail-cuff (timepoint not specified) \\
\hline & & mRNA (NB) & & Chga, Chgb & $\uparrow$ & Anesthesia not specified \\
\hline & & Protein (WB) & & CHGA & $\uparrow$ & Euthanasia not specified \\
\hline \multirow{2}{*}{$\begin{array}{l}\text { Reja et al. } \\
2002 \mathrm{~b}\end{array}$} & \multirow[t]{2}{*}{$18 \mathrm{w}$} & \multirow[t]{2}{*}{ mRNA (qPCR) } & \multirow[t]{2}{*}{$\mathrm{AM}$} & \multirow[t]{2}{*}{ Net } & \multirow[t]{2}{*}{$\uparrow$} & Tail-cuff 2 weeks before sampling \\
\hline & & & & & & $\begin{array}{c}\text { Euthanasia by sodium } \\
\text { pentobarbitone IP }\end{array}$ \\
\hline $\begin{array}{l}\text { Tsunoda and } \\
\text { Imai } 2004\end{array}$ & $20-25 w$ & Enzyme activity & AG & COMT & $=$ & Diethyl ether anesthesia \\
\hline \multirow{5}{*}{$\begin{array}{l}\text { Vavř́nová et } \\
\text { al. 2019a }\end{array}$} & \multirow[t]{2}{*}{$4 w$} & \multirow[t]{2}{*}{ mRNA (qPCR) } & $\mathrm{AM}$ & Vmat2, Npy & $\downarrow$ & Isoflurane \\
\hline & & & & $\begin{array}{l}\text { Vmat1, Chga, Chgb, Scg2, } \\
\text { Net, Maoa, Maob, Comt }\end{array}$ & $\begin{array}{l}= \\
=\end{array}$ & Exsanguination \\
\hline & $24 w$ & mRNA (qPCR) & & $\begin{array}{c}\text { Vmat1, Vmat2, Chga, Chgb, } \\
\text { Scg2, Npy, Net, Maoa }\end{array}$ & $\downarrow$ & \\
\hline & & & & Comt & $\begin{array}{l}\downarrow \\
=\end{array}$ & \\
\hline & & & & Maob & $\uparrow$ & \\
\hline
\end{tabular}


Catecholamine storage vesicles of the adrenal medulla contain remarkably high concentrations of chromogranins (encoded by Chga and Chgb genes), secretogranin ( $S c g 2$ gene), neuropeptide Y (Npy gene) and adenosine triphosphate (ATP). These molecules might influence the amount of catecholamines ready for exocytosis or when released they can mediate feedback regulation of catecholamine release from chromaffin cells (Burnstock 2014). Granins stabilize the vesicle core osmotically and they are involved in the regulation of exocytosis (Zhang et al. 2011). Chga knockout mice had the decreased size and number of chromaffin granules as well as the reduced adrenal content of epinephrine and norepinephrine (Mahapatra et al. 2005). In the adrenal medulla of prehypertensive SHR, the mRNA expression of Chga, Chgb and Scg2 was similar or slightly decreased compared to WKY rats (Friese et al. 2005, Vavřínová et al. 2019a). We reported the attenuated mRNA expression of Chga, Chgb and Scg2 genes in the adrenal medulla of adult SHR (Vavřínová et al. 2019a), whereas the increased mRNA and protein expression of Chga was shown in the adrenal medulla of adult SHR by O'Connor et al. (1999) and Nguyen et al. (2009). Nevertheless, the latter two studies used the repeated tail-cuff measurement of BP, which might influence the results of these studies. Thus, similarly with the genes involved in the catecholamine biosynthesis, the basal expression of granins seems to be downregulated in adrenal medulla of SHR, but the expression might be activated by stressful conditions such as tail-cuff measurement use.

Neuropeptide Y (NPY) is a peptide stored together with the catecholamines in the adrenal medulla which acts as a co-transmitter, a neuromodulator and a neurohormone (Lymperopoulos et al. 2016). NPY administered intravenously caused prolonged BP increase, which was augmented in SHR compared to WKY rats (Miller and Tessel 1991). Westfall et al. (1990) demonstrated that NPY potentiated the vasoconstriction of the mesenteric arterial bed induced by phenylephrine, angiotensin II and arginine vasopressin. This effect was enhanced in SHR compared to WKY rats. On the other hand, NPY decreased norepinephrine release from the mesenteric arterial bed evoked by periarterial nerve stimulation and this NPY action was attenuated in SHR (Westfall et al. 1990). Only few studies reported about the effect of NPY on chromaffin cells and their results are contradictory. NPY co-released due to cholinergic stimulation inhibited the parallel catecholamine secretion from cultured rat chromaffin cells (Shimoda et al. 1993). By contrast, Cavadas et al. (2006) showed that NPY increased catecholamine release from the cultured mouse chromaffin cells, but the constitutive catecholamine release from adrenal medulla was elevated in NPY $Y_{1}$ receptor knockout mice. Furthermore, it was reported that stress-induced increase of catecholamine release is prevented in NPY knockout mice (Wang et al. 2013). Apart from the effects on the catecholamine release NPY is also involved in the regulation of catecholamine biosynthesis. Hong et al. (1995) showed that acute intravenous NPY administration increased mRNA expression of $T h$ gene in rat adrenal medulla. On the other hand, NPY $\mathrm{Y}_{1}$ receptor knockout mice exhibited higher TH activity in the adrenal glands and the incubation with NPY decreased Th promotor activity in $\mathrm{Y}_{1}$ receptor expressing cells (Cavadas et al. 2006). In NPY knockout mice, basal TH immunoreactivity was increased in adrenals compared to wild-type animals suggesting that NPY exerts tonic inhibitory action on Th expression (Wang et al. 2013). In contrast, NPY knockout mice exhibited smaller stress-induced increase in the adrenal $\mathrm{TH}$ immunoreactivity than wildtype mice (Wang et al. 2013). Thus, the regulation of adrenal medulla by NPY is very complex and further investigation would be desirable. The decreased mRNA expression of $N p y$ gene was found in adrenal gland of young as well as adult SHR (Higuchi et al. 1993, Vavř́nová et al. 2019a). The contribution of lower NPY expression to the observed alterations in the adrenomedullary system in SHR remains to be elucidated.

\section{Catecholamine reuptake and degradation}

Catecholamine uptake at the neuroeffector junction is an important mechanism for the regulation of the synaptic norepinephrine concentrations. The catecholamine reuptake by norepinephrine transporter (NET, encoded by Slc6a2 gene) was enhanced in the blood vessels of SHR where it possibly compensates greater norepinephrine release from the sympathetic nerve endings (Whall et al. 1980, Hano and Rho 1989). On the other hand, the adrenal medulla is an endocrine organ and thus there is no reason for reuptake of released epinephrine and norepinephrine. Accordingly, the drugs using NET to enter the target cell (e.g. tyramine, 6-hydroxydopamine or guanethidine) work in the sympathetic 
nerve endings but they do not influence the adrenal medulla (Thoenen and Tranzer 1973, Johnson and O'Brien 1976, Wakade and Wakade 1984). However, NET was surprisingly present in epinephrine- but not in norepinephrine-producing cells of rat adrenal medulla (Phillips et al. 2001). Moreover, NET was shown to be localized primarily in the cytoplasm rather than in the cell membrane (Kippenberger et al. 1999, Phillips et al. 2001). Reja et al. (2002b) reported higher mRNA expression of Net in the adrenal medulla of adult SHR compared to WKY rats. By contrast, we observed lower mRNA expression of Net in the adrenal medulla of adult SHR, but similar Net expression in 4-week-old SHR and WKY rats (Vavř́nová et al. 2019a). However, the role of NET in rat adrenal chromaffin cells was not explained yet. Thus, it is not clear whether the altered mRNA expression of Net in adrenals of adult SHR might have any physiological effect.

Catecholamines are degraded by the enzymes monoamine oxidases (MAO, encoded by Maoa and $M a o b$ genes) or catechol-O-methyltransferase (COMT, encoded by Comt gene). Epinephrine is converted by COMT to more stable metanephrine. Norepinephrine can be converted by both MAO and COMT and thus several metabolites can be produced, e.g. 3,4-dihydroxymandelic acid, normetanephrine, vanillylmandelic acid etc. Sympathetic nerves contain only MAO, while adrenal medulla and other non-neural tissues contain both enzymes - MAO and COMT (Eisenhofer et al. 2004a). It was reported that adrenal medulla is a source of about $90 \%$ of circulating metanephrine and $30 \%$ of normetanephrine. However, this is rather a consequence of intracellular catecholamine metabolism following the leakage of norepinephrine and epinephrine from the chromaffin storage granules to the cytoplasm (MAO and COMT protecting the chromaffin cells from catecholamine toxicity) than the clearance of catecholamines from the extracellular space (Eisenhofer et al. 1995a, b). This process of catecholamine leakage was proposed to be an important mechanism for "gearing down" the requirement for necessary increases in catecholamine biosynthesis under the stress conditions, which provides a capacity for a more extended range of sustainable rates of catecholamine release (Eisenhofer et al. 2004b).

The decreased catecholamine degradation was observed in both neural and in non-neural tissues of SHR (Masuda et al. 2006, Tsunoda and Imai 2004). In the adrenal gland of prehypertensive SHR, microarray analysis revealed more than 30-fold higher mRNA expression of Comt but lower expression of Maob gene compared to WKY rats (Friese et al. 2005). However, these strain differences were not confirmed by our recent study (Vavř́nová et al. 2019a). In the adrenal medulla of adult SHR, slightly downregulated mRNA expression of Maoa, upregulated expression of Maob but unchanged expression of Comt was described (Vavrínová et al. 2019a). The activities of MAOA, MAOB and COMT were reported to be similar in the adrenals of adult SHR and WKY rats (Guffroy and Strollin Benedetti 1984, Tsunoda and Imai 2004). Taken together, the influence of catecholamine reuptake and degradation on the function of the adrenomedullary system is still not well understood. The studies concerning catecholamine reuptake and degradation are scarce and provide inconsistent results.

\section{Adrenergic receptors}

Adrenergic receptors are involved in the feedback regulation of catecholamine release. The activation of $\alpha_{2}$-adrenergic receptors inhibits catecholamine release from the sympathetic terminals, neurons in the brainstem as well as from the adrenal medulla (Brede et al. 2003, Gilsbach et al. 2009, Urban et al. 1995), thus exhibiting a hypotensive effect. As the adrenal medulla is an endocrine organ, the physiological role of $\alpha_{2}$-adrenergic receptors-mediated negative feedback in chromaffin cells is still questionable. However, PC12 rat pheochromocytoma cell line, which does not express $\alpha_{2}$-adrenergic receptors, secretes abnormal catecholamine quantities (Taraviras et al. 2002). The specific subtypes of $\alpha_{2}$-adrenergic receptors prevailing in the adrenal glands are still unknown and it seems there could be differences between species. In adrenal gland of the rat, mRNA expression of $\alpha_{2 \mathrm{~A}}, \alpha_{2 \mathrm{~B}}$ and $\alpha_{2 C}$ was detected (Moura et al. 2011, Behuliak and Vavřínová unpublished results). All three types were expressed similarly in the adrenal medulla of young as well as of adult SHR and WKY rats and the $\alpha_{2}$-mediated inhibition of catecholamine release was comparable in normotensive and hypertensive rats (Moura et al. 2011). By contrast, Reja et al. (2002a) reported lower mRNA expression of $\alpha_{2 \mathrm{~A}}$-adrenergic receptor subtype in adrenal medulla of adult SHR than in WKY rats. Furthermore, Friese et al. (2005) described decreased mRNA expression of $\alpha_{2 C^{-}}$and unchanged expression of $\alpha_{2 A^{-}}$and $\alpha_{2 B}$-adrenergic receptor subtypes in the adrenal gland of 
prehypertensive SHR. However, the comparison of mRNA expression results from various laboratories is quite complicated by the use of different conditions of quantitative real-time polymerase chain reaction and different reference genes for data normalization, which might influence the results (Vavř́nová et al. 2016).

$\beta$-adrenergic receptors facilitate norepinephrine release from the sympathetic terminals (Guimarães and Moura 2001). The stimulation of $\beta$-adrenergic receptors increases catecholamine release from bovine chromaffin cells (Parramón et al. 1995). $\beta_{1}$-adrenergic receptors mediated the slow potentiation of $\mathrm{Ca}^{2+}$ currents into the rat chromaffin cells. By contrast, $\beta_{2}$-adrenergic receptors caused the fast inhibition of $\mathrm{Ca}^{2+}$ currents in the rat adrenal medulla (Cesetti et al. 2003). Both mechanisms might be involved in the autocrine regulation of chromaffin cells, but their impact on catecholamine release has not been studied up to now. In rats with heart failure, the chronic treatment with $\beta_{1}$-adrenergic receptor blocker bisoprolol reduced catecholamine overproduction in the adrenal medulla (Rengo et al. 2012). Lower mRNA expression of $\beta_{2}$ - but unchanged expression of $\beta_{1}$ - and $\beta_{3}$-adrenergic receptor subtypes was reported in adrenal gland of young SHR (Friese et al. 2005). However, no physiological study determining the function of $\beta$-adrenergic receptors in the adrenal medulla of SHR has been published so far. Taken together, the study on the role of adrenal adrenergic receptors in the regulation of catecholamine release from chromaffin cells of SHR would be desirable since these receptors might alter calcium signaling and contribute to the enhancement of catecholamine release in SHR subjected to physical or psychological stressors.

\section{Adrenal demedullation}

There is clear evidence that the adrenomedullary system participates in the development of high blood pressure in SHR, but it is not a crucial cause of hypertension in this model. Adrenal demedullation performed in 4-week-old prehypertensive SHR attenuated but did not prevent the development of high BP in these rats (Borkowski and Quinn 1983, Borkowski 1991), the effect being reversed by epinephrine supplementation (Borkowski 1991). Chronic as well as acute adrenal demedullation decreased BP responses to the electrical stimulation in pithed rats, whereas it did not affect vascular smooth muscle contractility to phenylephrine (Borkowski and Quinn 1983). This suggests that epinephrine might potentiate norepinephrine release from the sympathetic nerve terminals. Indeed, a combination of sympathectomy with adrenal demedullation (Lee et al. 1991a, Lee et al. 1991b) or with $\alpha_{1}$-adrenergic blockade (Korner et al. 1993) completely prevented the development of high blood pressure in SHR. Moreover, epinephrine produced by the adrenal medulla might be involved in vascular hypertrophy and remodeling in SHR (Lee et al. 1991a, Lee et al. 1991b, Korner et al. 1993). These early structural and functional changes of cardiovascular system induced by pronounced activation of the adrenomedullary system (in cooperation with sympathoneural system) in immature SHR are probably irreversible because the effects of adrenal demedullation became insignificant since the age of 7 weeks (Borkowski 1991). Thus it seems that the adrenomedullary system does not actively contribute to the maintenance of high blood pressure in adult SHR. This is also in line with the age-dependent downregulation of catecholamine biosynthetic pathway described in the adrenal medulla of SHR with established hypertension (Vavř́nová et al. 2019a). However, the adrenomedullary system might substitute the function of the suppressed sympathoneural system in both young and adult rats. The increased adrenal catecholamine content and the elevated plasma levels of epinephrine were demonstrated in rats treated neonatally or in adulthood with the sympatholytic drug guanethidine (Korner et al. 1993, Tipton et al. 1984, Vavř́nová et al. 2019b). The activation of the adrenomedullary system in sympathectomized rats is probably mediated centrally because peripheral sympathectomy by 6-hydroxydopamine increased Fos immunoreactivity in many brain nuclei, including PVN (Callahan et al. 1998). Thereby, the activation of the adrenomedullary system might oppose the blood pressure lowering effects of the treatment targeting peripheral sympathetic system in SHR, being one of the reasons for the resistance of adult SHR to the treatment of hypertension.

\section{Conclusions}

Spontaneously hypertensive rats (SHR) exhibit numerous abnormalities in the adrenomedullary system from the hyperactivity of brain centers regulating sympathetic outflow, through the exaggerated activation of sympathoadrenal preganglionic neurons, the altered morphology of adrenal medulla, up to the local changes in catecholamine biosynthesis, storage and degradation in 
chromaffin cells. Although it is quite difficult to highlight one particular abnormality that would be responsible for the development and maintenance of high blood pressure in SHR, the present evidence suggests that this hypertensive strain is highly prone to various stressful stimuli. This is apparent already from the prehypertensive stage and hence the repeated excessive activation of the adrenomedullary system and the enhanced catecholamine release can promote other pathological changes observed in SHR, including the potentiation of norepinephrine release from the sympathetic nerve terminals or the structural changes of vascular arteries. Indeed, hypertension development is attenuated in animals subjected to adrenal demedullation before the age of 7 weeks and the combination of demedullation with neonatal sympathectomy normalized blood pressure of SHR to the level of normotensive controls. The deleterious effects of the stress are widely accepted and therefore SHR could be a suitable model for studying the connection between the stress susceptibility and the development of cardiovascular diseases. On the other hand, the contribution of the adrenomedullary system to the maintenance of high blood pressure in adult SHR seems to be minimal. Actually, the expression of genes involved in catecholamine biosynthesis and genes related to catecholamine vesicles is downregulated in adult stress-naïve SHR, but their adrenomedullary system is still more responsive to stressful conditions. Moreover, the activation of the adrenomedullary system is one of the mechanisms opposing the blood pressure lowering effects of treatment targeting peripheral sympathetic system in SHR. This finding points out to the interconnection of particular systems involved in the regulation of blood pressure and their mutual substitution. It also suggests that the treatments targeting central regulation of blood pressure might be effective for the lowering of blood pressure in hypertension in general.

\section{Conflict of Interest}

There is no conflict of interest.

\section{Acknowledgements}

This work was supported by Czech Science Foundation (GACR 16-1034Y) and Joint Project of GACR and MOST, Taiwan (grant Nr. 19-08260J).

\section{References}

ALLEN AM: Inhibition of the hypothalamic paraventricular nucleus in spontaneously hypertensive rats dramatically reduces sympathetic vasomotor tone. Hypertension 39: 275-280, 2002. https://doi.org/10.1161/hy0202.104272

AXELROD J, REISINE TD: Stress hormones: their interaction and regulation. Science 224: 452-459, 1984. https://doi.org/10.1126/science.6143403

BEHULIAK M, BENCZE M, POLGÁROVÁ K, KUNEŠ J, VANĚČKOVÁ I, ZICHA J: Hemodynamic response to gabapentin in conscious spontaneously hypertensive rats. Hypertension 72: 676-685, 2018. https://doi.org/10.1161/HYPERTENSIONAHA.118.09909

BEHULIAK M, VAVŘ́NOVÁ A, BENCZE M, POLGÁROVÁ K, ERGANG P, KUNEŠ J, VANĚČKOVÁ I, ZICHA $\mathrm{J}$ : Ontogenetic changes in contribution of calcium sensitization and calcium entry to blood pressure maintenance of Wistar-Kyoto and spontaneously hypertensive rats. J Hypertens 33: 2443-2454, 2015. https://doi.org/10.1097/HJH.0000000000000746

BLAKELY RD, EDWARDS RH: Vesicular and plasma membrane transporters for neurotransmitters. Cold Spring Harb Perspect Biol 4: a005595, 2012. https://doi.org/10.1101/cshperspect.a005595

BLASCHKO H: The activity of 1(-)-dopa decarboxylase. J Physiol 101: 337-349, 1942. https://doi.org/10.1113/jphysiol.1942.sp003988

BOMFIM GHS, MÉNDEZ-LÓPEZ I, FERNÁNDEZ-MORALES JC, PADÍN JF, JURKIEWICZ A, JURKIEWICZ NH, GARCÍA AG: Electrophysiological properties and augmented catecholamine release from chromaffin cells of WKY and SHR rats contributing to the hypertension development elicited by chronic EtOH consumption. Eur J Pharmacol 803: 65-77, 2017. https://doi.org/10.1016/j.ejphar.2017.03.017

BORKOWSKI KR: Effect of adrenal demedullation and adrenaline on hypertension development and vascular reactivity in young spontaneously hypertensive rats. J Auton Pharmacol 11: 1-14, 1991. https://doi.org/10.1111/j.1474-8673.1991.tb00239.x 
BORKOWSKI KR, QUINN P: The effect of bilateral adrenal demedullation on vascular reactivity and blood pressure in spontaneously hypertensive rats. Br J Pharmacol 80: 429-437, 1983. https://doi.org/10.1111/j.14765381.1983.tb10712.x

BREDE M, NAGY G, PHILIPP M, SORENSEN JB, LOHSE MJ, HEIN L: Differential control of adrenal and sympathetic catecholamine release by alpha 2-adrenoceptor subtypes. Mol Endocrinol 17: 1640-1646, 2003. https://doi.org/10.1210/me.2003-0035

BROWN MR, HAUGER R, FISHER LA: Autonomic and cardiovascular effects of corticotropin-releasing factor in the spontaneously hypertensive rat. Brain Res 441: 33-40, 1988. https://doi.org/10.1016/0006-8993(88)91380-7

BURGOYNE RD: Control of exocytosis in adrenal chromaffin cells. Biochim Biophys Acta 1071: 174-202, 1991. https://doi.org/10.1016/0304-4157(91)90024-Q

BURNSTOCK G: Purinergic signalling in endocrine organs. Purinergic Signal 10: 189-231, 2014. https://doi.org/10.1007/s11302-013-9396-X

CALLAHAN TA, MOYNIHAN JA, PIEKUT DT: Central nervous system activation following peripheral chemical sympathectomy: implications for neural-immune interactions. Brain Behav Immun 12: 230-241, 1998. https://doi.org/10.1006/brbi.1998.0526

CAVADAS C, CÉFAI D, ROSMANINHO-SALGADO J, VIEIRA-COELHO MA, MOURA E, BUSSO N, PEDRAZZINI T, GRAND D, ROTMAN S, WAEBER B, AUBERT JF, GROUZMANN E: Deletion of the neuropeptide Y (NPY) Y1 receptor gene reveals a regulatory role of NPY on catecholamine synthesis and secretion. Proc Natl Acad Sci U S A 103: 10497-10502, 2006. https://doi.org/10.1073/pnas.0600913103

CESETTI T, HERNÁNDEZ-GUIJO JM, BALDELLI P, CARABELLI V, CARBONE E: Opposite action of beta1- and beta2-adrenergic receptors on $\mathrm{Ca}(\mathrm{V}) 1 \mathrm{~L}$-channel current in rat adrenal chromaffin cells. J Neurosci 23: 73-83, 2003. https://doi.org/10.1523/JNEUROSCI.23-01-00073.2003

DAMPNEY RA: Central neural control of the cardiovascular system: current perspectives. Adv Physiol Educ 40: 283-296, 2016. https://doi.org/10.1152/advan.00027.2016

DE DIEGO AM, GANDÍA L, GARCÍA AG: A physiological view of the central and peripheral mechanisms that regulate the release of catecholamines at the adrenal medulla. Acta Physiol (Oxf) 192: 287-301, 2008. https://doi.org/10.1111/j.1748-1716.2007.01807.x

DE PASCUAL R, MIRANDA-FERREIRA R, GALVÃO KM, LAMEU C, ULRICH H, SMAILI SS, JURKIEWICZ A, GARCÍA AG, GANDÍA L: Lower density of L-type and higher density of P/Q-type of calcium channels in chromaffin cells of hypertensive, compared with normotensive rats. Eur J Pharmacol 706: 25-35, 2013. https://doi.org/10.1016/j.ejphar.2013.02.046

EISENHOFER G, FRIBERG P, PACAK K, GOLDSTEIN DS, MURPHY DL, TSIGOS C, QUYYUMI AA, BRUNNER HG, LENDERS JW: Plasma metadrenalines: do they provide useful information about sympathoadrenal function and catecholamine metabolism? Clin Sci (Lond) 88: 533-542, $1995 \mathrm{a}$. https://doi.org/10.1042/cs0880533

EISENHOFER G, KOPIN IJ, GOLDSTEIN DS: Catecholamine metabolism: a contemporary view with implications for physiology and medicine. Pharmacol Rev 56: 331-349, 2004a. https://doi.org/10.1124/pr.56.3.1

EISENHOFER G, KOPIN IJ, GOLDSTEIN DS: Leaky catecholamine stores: undue waste or a stress response coping mechanism? Ann N Y Acad Sci 1018: 224-230, 2004b. https://doi.org/10.1196/annals.1296.027

EISENHOFER G, RUNDQUIST B, ANEMAN A, FRIBERG P, DAKAK N, KOPIN IJ, JACOBS MC, LENDERS JW: Regional release and removal of catecholamines and extraneuronal metabolism to metanephrines. J Clin Endocrinol Metab 80: 3009-3017, 1995b. https://doi.org/10.1210/jcem.80.10.7559889

ELAM M, GRASSI G: Adrenaline and hypertension: new evidence for a guilty verdict? J Hypertens 18: 675-677, 2000. https://doi.org/10.1097/00004872-200018060-00003

FERRARI AU, DAFFONCHIO A, FRANZELLI C, MANCIA G: Potentiation of the baroreceptor-heart rate reflex by sympathectomy in conscious rats. Hypertension 18: 230-235, 1991. https://doi.org/10.1161/01.HYP.18.2.230

FISHER JP, PATON JF: The sympathetic nervous system and blood pressure in humans: implications for hypertension. J Hum Hypertens 26: 463-475, 2012. https://doi.org/10.1038/jhh.2011.66

FLATMARK T: Catecholamine biosynthesis and physiological regulation in neuroendocrine cells. Acta Physiol Scand 168: 1-17, 2000. https://doi.org/10.1046/j.1365-201x.2000.00596.x 
FLORAS JS: Epinephrine and the genesis of hypertension. Hypertension 19: 1-18, 1992. https://doi.org/10.1161/01.HYP.19.1.1

FRIEDMAN S, KAUFMAN S: 3,4-dihydroxyphenylethylamine beta-hydroxylase. Physical properties, copper content, and role of copper in the catalytic acttivity. J Biol Chem 240: 4763-4773, 1965. https://doi.org/10.1016/S00219258(18)97021-3

FRIESE RS, MAHBOUBI P, MAHAPATRA NR, MAHATA SK, SCHORK NJ, SCHMID-SCHÖNBEIN GW, O'CONNOR DT: Common genetic mechanisms of blood pressure elevation in two independent rodent models of human essential hypertension. Am J Hypertens 18: 633-652, 2005. https://doi.org/10.1016/j.amjhyper.2004.11.037

GAVRILOVIC L, SPASOJEVIC N, TANIC N, DRONJAK S: Chronic isolation of adult rats decreases gene expression of catecholamine biosynthetic enzymes in adrenal medulla. Neuro Endocrinol Lett 29: 1015-1020, 2008.

GERALDES V, GONCALVES-ROSA N, LIU B, PATON JF, ROCHA I: Essential role of RVL medullary neuronal activity in the long term maintenance of hypertension in conscious SHR. Auton Neurosci 186: 22-31, 2014. https://doi.org/10.1016/j.autneu.2014.09.002

GERALDES V, GONCALVES-ROSA N, TAVARES C, PATON JFR, ROCHA I: Reversing gene expression in cardiovascular target organs following chronic depression of the paraventricular nucleus of hypothalamus and rostral ventrolateral medulla in spontaneous hypertensive rats. Brain Res 1646: 109-115, 2016. https://doi.org/10.1016/j.brainres.2016.05.041

GILSBACH R, RÖSER C, BEETZ N, BREDE M, HADAMEK K, HAUBOLD M, LEEMHUIS J, PHILIPP M, SCHNEIDER J, URBANSKI M, SZABO B, WEINSHENKER D, HEIN L: Genetic dissection of alpha2adrenoceptor functions in adrenergic versus nonadrenergic cells. Mol Pharmacol 75: 1160-1170, 2009. https://doi.org/10.1124/mol.109.054544

GROBECKER H, SAAVEDRA JM, ROIZEN MF, WEISE V, KOPIN IJ, AXELROD J: Peripheral and central catecholaminergic neurons in genetic and experimental hypertension in rats. Clin Sci Mol Med Suppl 3: 377s-380s, 1976. https://doi.org/10.1042/cs051377s

GRUNDT A, GRUNDT C, GORBEY S, THOMAS MA, LEMMER B: Strain-dependent differences of restraint stressinduced hypertension in WKY and SHR. Physiol Behav 97: 341-346, 2009. https://doi.org/10.1016/j.physbeh.2009.02.029

GUÉRINEAU NC: Cholinergic and peptidergic neurotransmission in the adrenal medulla: A dynamic control of stimulus-secretion coupling. IUBMB Life 72: 553-567, 2020. https://doi.org/10.1002/iub.2117

GUFFROY C, STROLIN BENEDETTI M: Monoamine oxidase and semicarbazide-sensitive amine oxidase in spontaneously hypertensive and in normotensive control rats. Life Sci 34: 535-545, 1984. https://doi.org/10.1016/0024-3205(84)90486-7

GUIMARÃES S, MOURA D: Vascular adrenoceptors: an update. Pharmacol Rev 53: 319-356, 2001.

GUYENET PG: The sympathetic control of blood pressure. Nat Rev Neurosci 7: 335-346, 2006. https://doi.org/10.1038/nrn1902

HAJÓS M, ENGBERG G: Emotional hyperthermia in spontaneously hypertensive rats. Psychopharmacology (Berl) 90: 170-172, 1986. https://doi.org/10.1007/BF00181235

HANO T, RHO J: Norepinephrine overflow in perfused mesenteric arteries of spontaneously hypertensive rats. Hypertension 14: 44-53, 1989. https://doi.org/10.1161/01.HYP.14.1.44

HASHIMOTO K, MAKINO S, HIRASAWA R, TAKAO T, SUGAWARA M, MURAKAMI K, ONO K, OTA Z: Abnormalities in the hypothalamo-pituitary-adrenal axis in spontaneously hypertensive rats during development of hypertension. Endocrinology 125: 1161-1167, 1989. https://doi.org/10.1210/endo-125-3-1161

HATTORI T, HASHIMOTO K, OTA Z: Adrenocorticotropin responses to corticotropin releasing factor and vasopressin in spontaneously hypertensive rats. Hypertension 8: 386-390, 1986. https://doi.org/10.1161/01.HYP.8.5.386

HIGUCHI H, NAKANO K, IWASA A: Decrease in prepro-neuropeptide Y gene expression in the adrenal gland and cerebral cortex of spontaneously hypertensive rats. Neuropeptides 25: 343-349, 1993. https://doi.org/10.1016/01434179(93)90053-D

HONG M, LI S, FOURNIER A, ST-PIERRE S, PELLETIER G: Role of neuropeptide Y in the regulation of tyrosine hydroxylase gene expression in rat adrenal glands. Neuroendocrinology 61: 85-88, 1995. https://doi.org/10.1159/000126816 
JANSEN AS, NGUYEN XV, KARPITSKIY V, METTENLEITER TC, LOEWY AD: Central command neurons of the sympathetic nervous system: basis of the fight-or-flight response. Science 270: 644-646, 1995. https://doi.org/10.1126/science.270.5236.644

JIROUT ML, FRIESE RS, MAHAPATRA NR, MAHATA M, TAUPENOT L, MAHATA SK, KREN V, ZÍDEK V, FISCHER J, MAATZ H, ZIEGLER MG, PRAVENEC M, HUBNER N, AITMAN TJ, SCHORK NJ, O'CONNOR DT: Genetic regulation of catecholamine synthesis, storage and secretion in the spontaneously hypertensive rat. Hum Mol Genet 19: 2567-2580, 2010. https://doi.org/10.1093/hmg/ddq135

JOHNSON EM JR, O'BRIEN F: Evaluation of the permanent sympathectomy produced by the administration of guanethidine to adult rats. J Pharmacol Exp Ther 196: 53-61, 1976.

JUDY WV, FARRELL SK: Arterial baroreceptor reflex control of sympathetic nerve activity in the spontaneously hypertensive rat. Hypertension 1: 605-614, 1979. https://doi.org/10.1161/01.HYP.1.6.605

KHALIL Z, MARLEY PD, LIVETT BG: Elevation in plasma catecholamines in response to insulin stress is under both neuronal and nonneuronal control. Endocrinology 119: 159-167, 1986. https://doi.org/10.1210/endo-119-1-159

KIPPENBERGER AG, PALMER DJ, COMER AM, LIPSKI J, BURTON LD, CHRISTIE DL: Localization of the noradrenaline transporter in rat adrenal medulla and PC12 cells: evidence for its association with secretory granules in PC12 cells. J Neurochem 73: 1024-1032, 1999. https://doi.org/10.1046/j.1471-4159.1999.0731024.x

KORNER P, BOBIK A, ODDIE C, FRIBERG P: Sympathoadrenal system is critical for structural changes in genetic hypertension. Hypertension 22: 243-252, 1993. https://doi.org/10.1161/01.HYP.22.2.243

KUMAI T, TANAKA M, WATANABE M, KOBAYASHI S: Elevated tyrosine hydroxylase mRNA levels in the adrenal medulla of spontaneously hypertensive rats. Jpn J Pharmacol 65: 367-369, 1994. https://doi.org/10.1254/jip.65.367

KUMAI T, TATEISHI T, TANAKA M, WATANABE M, SHIMIZU H, KOBAYASHI S: Tyrosine hydroxylase antisense gene therapy causes hypotensive effects in the spontaneously hypertensive rats. J Hypertens 19: 1769-1773, 2001. https://doi.org/10.1097/00004872-200110000-00010

KVETNANSKY R, MCCARTY R, THOA NB, LAKE CR, KOPIN IJ: Sympatho-adrenal responses of spontaneously hypertensive rats to immobilization stress. Am J Physiol 236: H457-H462, 1979. https://doi.org/10.1152/ajpheart.1979.236.3.H457

KVETNANSKY R, MICUTKOVA L, RYCHKOVA N, KUBOVCAKOVA L, MRAVEC B, FILIPENKO M, SABBAN EL, KRIZANOVA O: Quantitative evaluation of catecholamine enzymes gene expression in adrenal medulla and sympathetic Ganglia of stressed rats. Ann N Y Acad Sci 1018: 356-669, 2004. https://doi.org/10.1196/annals.1296.045

KVETNANSKY R, SABBAN EL, PALKOVITS M: Catecholaminergic systems in stress: structural and molecular genetic approaches. Physiol Rev 89: 535-606, 2009. https://doi.org/10.1152/physrev.00042.2006

LEE RM, TRIGGLE CR, CHEUNG DW, COUGHLIN MD: Structural and functional consequence of neonatal sympathectomy on the blood vessels of spontaneously hypertensive rats. Hypertension 10: 328-338, 1987. https://doi.org/10.1161/01.HYP.10.3.328

LEE RM, BORKOWSKI KR, LEENEN FH, TSOPORIS J, COUGHLIN M: Combined effect of neonatal sympathectomy and adrenal demedullation on blood pressure and vascular changes in spontaneously hypertensive rats. Circ Res 69: 714-721, 1991a. https://doi.org/10.1161/01.RES.69.3.714

LEE RM, BORKOWSKI KR, LEENEN FH, TSOPORIS J, COUGHLIN M: Interaction between sympathetic nervous system and adrenal medulla in the control of cardiovascular changes in hypertension. J Cardiovasc Pharmacol 17 (Suppl 2): S114-S116, 1991b. https://doi.org/10.1097/00005344-199117002-00025

LI DP, YANG Q, PAN HM, PAN HL: Pre- and postsynaptic plasticity underlying augmented glutamatergic inputs to hypothalamic presympathetic neurons in spontaneously hypertensive rats. J Physiol 586: 1637-1647, 2008. https://doi.org/10.1113/jphysiol.2007.149732

LIM DY, JANG SJ, PARK DG: Comparison of catecholamine release in the isolated adrenal glands of SHR and WKY rats. Auton Autacoid Pharmacol 22: 225-232, 2002. https://doi.org/10.1046/j.1474-8673.2002.00264.x

LIVETT BG, MARLEY PD: Noncholinergic control of adrenal catecholamine secretion. J Anat 183: 277-289, 1993.

LYMPEROPOULOS A, BRILL A, MCCRINK KA: GPCRs of adrenal chromaffin cells \& catecholamines: The plot thickens. Int J Biochem Cell Biol 77: 213-219, 2016. https://doi.org/10.1016/j.biocel.2016.02.003

MAHAPATRA NR, O'CONNOR DT, VAINGANKAR SM, HIKIM AP, MAHATA M, RAY S, STAITE E, WU H, GU Y, DALTON N, KENNEDY BP, ZIEGLER MG, ROSS J, MAHATA SK: Hypertension from targeted 
ablation of chromogranin A can be rescued by the human ortholog. J Clin Invest 115: 1942-1952, 2005. https://doi.org/10.1172/JCI24354

MANCIA G, GRASSI G: The autonomic nervous system and hypertension. Circ Res 114: 1804-1814, 2014. https://doi.org/10.1161/CIRCRESAHA.114.302524

MASUDA M, TSUNODA M, IMAI K: Low catechol-O-methyltransferase activity in the brain and blood pressure regulation. Biol Pharm Bull 29: 202-205, 2006. https://doi.org/10.1248/bpb.29.202

MATSUURA T, KUMAGAI H, KAWAI A, ONIMARU H, IMAI M, OSHIMA N, SAKATA K, SARUTA T: Rostral ventrolateral medulla neurons of neonatal Wistar-Kyoto and spontaneously hypertensive rats. Hypertension 40: 560-565, 2002. https://doi.org/10.1161/01.HYP.0000032043.64223.87

MCALLEN RM, MAY CN: Differential drives from rostral ventrolateral medullary neurons to three identified sympathetic outflows. Am J Physiol 267: R935-R944, 1994. https://doi.org/10.1152/ajpregu.1994.267.4.R935

MCCARTY R, HORWATT K, KONARSKA M: Chronic stress and sympathetic-adrenal medullary responsiveness. Soc Sci Med 26: 333-341, 1988. https://doi.org/10.1016/0277-9536(88)90398-X

MCCARTY R, KVETNANSKY R, LAKE CR, THOA NB, KOPIN IJ: Sympatho-adrenal activity of SHR and WKY rats during recovery from forced immobilization. Physiol Behav 21: 951-955, 1978. https://doi.org/10.1016/0031-9384(78)90171-3

MILLER DW, TESSEL RE: Age-dependent hyperresponsiveness of spontaneously hypertensive rats to the pressor effects of intravenous neuropeptide Y (NPY): role of mode of peptide administration and plasma NPY-like immunoreactivity. J Cardiovasc Pharmacol 18: 647-656, 1991. https://doi.org/10.1097/00005344-199111000-00001

MINSON J, ARNOLDA L, LLEWELLYN-SMITH I, PILOWSKY P, CHALMERS J: Altered c-fos in rostral medulla and spinal cord of spontaneously hypertensive rats. Hypertension 27: 433-441, 1996. https://doi.org/10.1161/01.HYP.27.3.433

MIRANDA-FERREIRA R, DE PASCUAL R, DE DIEGO AM, CARICATI-NETO A, GANDÍA L, JURKIEWICZ A, GARCÍA AG: Single-vesicle catecholamine release has greater quantal content and faster kinetics in chromaffin cells from hypertensive, as compared with normotensive, rats. J Pharmacol Exp Ther 324: 685-693, 2008. https://doi.org/10.1124/jpet.107.128819

MORRISON SF, WHITEHORN D: Enhanced preganglionic sympathetic nerve responses in spontaneously hypertensive rats. Brain Res 296: 152-155, 1984. https://doi.org/10.1016/0006-8993(84)90522-5

MORRISON SF, CAO WH: Different adrenal sympathetic preganglionic neurons regulate epinephrine and norepinephrine secretion. Am J Physiol Regul Integr Comp Physiol 279: R1763-R1775, 2000. https://doi.org/10.1152/ajpregu.2000.279.5.R1763

MOURA E, PINHO COSTA PM, MOURA D, GUIMARÃES S, VIEIRA-COELHO MA: Decreased tyrosine hydroxylase activity in the adrenals of spontaneously hypertensive rats. Life Sci 76: 2953-2964, 2005. https://doi.org/10.1016/j.lfs.2004.11.017

MOURA E, PINTO CE, CALÓ A, SERRÃO MP, AFONSO J, VIEIRA-COELHO MA: $\alpha_{2}$-Adrenoceptor-mediated inhibition of catecholamine release from the adrenal medulla of spontaneously hypertensive rats is preserved in the early stages of hypertension. Basic Clin Pharmacol Toxicol 109: 253-260, 2011. https://doi.org/10.1111/j.1742-7843.2011.00712.x

MRAVEC B: A new focus on interoceptive properties of adrenal medulla. Auton Neurosci 120: 10-17, 2005. https://doi.org/10.1016/j.autneu.2005.04.005

MUELLER PJ, MISCHEL NA, SCISLO TJ: Differential activation of adrenal, renal, and lumbar sympathetic nerves following stimulation of the rostral ventrolateral medulla of the rat. Am J Physiol Regul Integr Comp Physiol 300: R1230-R1240, 2011. https://doi.org/10.1152/ajpregu.00713.2010

NAGATSU T, IKUTA K, NUMATA Y, KATO T, SANO M: Vascular and brain dopamine beta-hydroxylase activity in young spontaneously hypertensive rats. Science 191: 290-291, 1976. https://doi.org/10.1126/science. 1858

NAGATSU T, LEVITT M, UDENFRIEND S: Tyrosine hydroxylase. The initial step in norepinephrine biosynthesis. J Biol Chem 239: 2910-2917, 1964. https://doi.org/10.1016/S0021-9258(18)93832-9

NGUYEN P, PELTSCH H, DE WIT J, CRISPO J, UBRIACO G, EIBL J, TAI TC: Regulation of the phenylethanolamine N-methyltransferase gene in the adrenal gland of the spontaneous hypertensive rat. Neurosci Lett 461: 280-284, 2009. https://doi.org/10.1016/j.neulet.2009.06.022 
O'CONNOR DT, TAKIYYUDDIN MA, PRINTZ MP, DINH TQ, BARBOSA JA, ROZANSKY DJ, MAHATA SK, WU H, KENNEDY BP, ZIEGLER MG, WRIGHT FA, SCHLAGER G, PARMER RJ: Catecholamine storage vesicle protein expression in genetic hypertension. Blood Press 8: 285-295, 1999. https://doi.org/10.1080/080370599439508

ONDICOVA K, MRAVEC B: Multilevel interactions between the sympathetic and parasympathetic nervous systems: a minireview. Endocr Regul 44: 69-75, 2010. https://doi.org/10.4149/endo_2010_02_69

PALMER AA, PRINTZ MP: Strain differences in Fos expression following airpuff startle in Spontaneously Hypertensive and Wistar Kyoto rats. Neuroscience 89: 965-978, 1999. https://doi.org/10.1016/S03064522(98)00333-9

PARRAMÓN M, GONZÁLEZ MP, OSET-GASQUE MJ: A reassessment of the modulatory role of cyclic AMP in catecholamine secretion by chromaffin cells. $\mathrm{Br} J$ Pharmacol 114: 517-523, 1995. https://doi.org/10.1111/j.1476-5381.1995.tb13257.x

PHILLIPS JK, DUBEY R, SESIASHVILVI E, TAKEDA M, CHRISTIE DL, LIPSKI J: Differential expression of the noradrenaline transporter in adrenergic chromaffin cells, ganglion cells and nerve fibres of the rat adrenal medulla. J Chem Neuroanat 21: 95-104, 2001. https://doi.org/10.1016/S0891-0618(00)00113-7

PINTÉROVÁ M, KUNEŠ J, ZICHA J: Altered neural and vascular mechanisms in hypertension. Physiol Res 60: 381-402, 2011. https://doi.org/10.33549/physiolres. 932189

PRAVENEC M, LANDA V, ZÍDEK V, MLEJNEK P, ŠILHAVÝ J, MIR SA, VAINGANKAR SM, WANG J, KURTZ TW: Effects of transgenic expression of dopamine beta hydroxylase (Dbh) gene on blood pressure in spontaneously hypertensive rats. Physiol Res 65: 1039-1044, 2016. https://doi.org/10.33549/physiolres.933490

PYNER S, COOTE JH: Evidence that sympathetic preganglionic neurones are arranged in target-specific columns in the thoracic spinal cord of the rat. J Comp Neurol 342: 15-22, 1994. https://doi.org/10.1002/cne.903420103

PYNER S, COOTE JH: Rostroventrolateral medulla neurons preferentially project to target-specified sympathetic preganglionic neurons. Neuroscience 83: 617-631, 1998. https://doi.org/10.1016/S0306-4522(97)00355-2

REJA V, GOODCHILD AK, PHILLIPS JK, PILOWSKY PM: Tyrosine hydroxylase gene expression in ventrolateral medulla oblongata of WKY and SHR: a quantitative real-time polymerase chain reaction study. Auton Neurosci 98: 79-84, 2002a. https://doi.org/10.1016/S1566-0702(02)00037-1

REJA V, GOODCHILD AK, PILOWSKY PM: Catecholamine-related gene expression correlates with blood pressures in SHR. Hypertension 40: 342-347, 2002b. https://doi.org/10.1161/01.HYP.0000027684.06638.63

RENGO G, LYMPEROPOULOS A, ZINCARELLI C, FEMMINELLA G, LICCARDO D, PAGANO G, DE LUCIA C, CANNAVO A, GARGIULO P, FERRARA N, PERRONE FILARDI P, KOCH W, LEOSCO D: Blockade of $\beta$-adrenoceptors restores the GRK2-mediated adrenal $\alpha(2)$-adrenoceptor-catecholamine production axis in heart failure. Br J Pharmacol 166: 2430-2440, 2012. https://doi.org/10.1111/j.1476-5381.2012.01972.x

RICKSTEN SE, LUNDIN S, THOREN P: Spontaneous variations in arterial blood pressure, heart rate and sympathetic nerve activity in conscious normotensive and spontaneously hypertensive rats. Acta Physiol Scand 120: 595-600, 1984. https://doi.org/10.1111/j.1748-1716.1984.tb07425.x

SCHIEKEN RM: The effect of diazepam upon the development of hypertension in the spontaneously hypertensive rat. Pediatr Res 13: 992-996, 1979. https://doi.org/10.1203/00006450-197909000-00008

SCHRAMM LP, CHORNOBOY ES: Sympathetic activity in spontaneously hypertensive rats after spinal transection. Am J Physiol 243: R506-R511, 1982. https://doi.org/10.1152/ajpregu.1982.243.5.R506

SHIMODA K, SHEN GH, PFEIFFER RF, MCCOMB RD, YANG HY: Antiserum against neuropeptide Y enhances the nicotine-mediated release of catecholamines from cultured rat adrenal chromaffin cells. Neurochem Int 23: 71-77, 1993. https://doi.org/10.1016/0197-0186(93)90145-U

SMITH TL, HUTCHINS PM: Central hemodynamics in the developmental stage of spontaneous hypertension in the unanesthetized rat. Hypertension 1: 508-517, 1979. https://doi.org/10.1161/01.HYP.1.5.508

STACHOWIAK MK, JIANG HK, POISNER AM, TUOMINEN RK, HONG JS: Short and long term regulation of catecholamine biosynthetic enzymes by angiotensin in cultured adrenal medullary cells. Molecular mechanisms and nature of second messenger systems. J Biol Chem 265: 4694-4702, 1990. https://doi.org/10.1016/S0021-9258(19)39618-8

STERLEY TL, HOWELLS FM, RUSSELL VA: Effects of early life trauma are dependent on genetic predisposition: a rat study. Behav Brain Funct 7: 11, 2011. https://doi.org/10.1186/1744-9081-7-11 
STERN JE, SONNER PM, SON SJ, SILVA FC, JACKSON K, MICHELINI LC: Exercise training normalizes an increased neuronal excitability of NTS-projecting neurons of the hypothalamic paraventricular nucleus in hypertensive rats. J Neurophysiol 107: 2912-2921, 2012. https://doi.org/10.1152/jn.00884.2011

STRACK AM, SAWYER WB, PLATT KB, LOEWY AD: CNS cell groups regulating the sympathetic outflow to adrenal gland as revealed by transneuronal cell body labeling with pseudorabies virus. Brain Res 491: 274-296, 1989. https://doi.org/10.1016/0006-8993(89)90063-2

SUZUKI H, DELANO FA, JAMSHIDI N, KATZ D, MORI M, KOSAKI K, GOTTLIEB RA, ISHII H, SCHMIDSCHÖNBEIN GW: Enhanced DNA fragmentation in the thymus of spontaneously hypertensive rats. Am J Physiol 276: H2135-H2140, 1999. https://doi.org/10.1152/ajpheart.1999.276.6.H2135

SZEMEREDI K, BAGDY G, STULL R, KEISER HR, KOPIN IJ, GOLDSTEIN DS: Sympathoadrenomedullary hyperresponsiveness to yohimbine in juvenile spontaneously hypertensive rats. Life Sci 43: 1063-1068, 1988. https://doi.org/10.1016/0024-3205(88)90201-9

TABEI R, FUJIWARA T, KONDO M, TERADA M: Morphological studies on the paraneuron in spontaneously hypertensive rats. Clin Exp Hypertens A 10 (Suppl 1): 235-247, 1988. https://doi.org/10.3109/10641968809075975

TAKEDA K, BUÑAG RD: Sympathetic hyperactivity during hypothalamic stimulation in spontaneously hypertensive rats. J Clin Invest 62: 642-648, 1978. https://doi.org/10.1172/JCI109171

TARAVIRAS S, OLLI-LÄHDESMÄKI T, LYMPEROPOULOS A, CHARITONIDOU D, MAVROIDIS M, KALLIO J, SCHEININ M, FLORDELLIS C: Subtype-specific neuronal differentiation of PC12 cells transfected with alpha2-adrenergic receptors. Eur J Cell Biol 81: 363-374, 2002. https://doi.org/10.1078/0171-9335-00250

TEKIN I, ROSKOSKI R JR, CARKACI-SALLI N, VRANA KE: Complex molecular regulation of tyrosine hydroxylase. J Neural Transm (Vienna) 121: 1451-1481, 2014. https://doi.org/10.1007/s00702-014-1238-7

THOENEN H, TRANZER JP: The pharmacology of 6-hydroxydopamine. Annu Rev Pharmacol 13: 169-180, 1973. https://doi.org/10.1146/annurev.pa.13.040173.001125

THÖNY B, AUERBACH G, BLAU N: Tetrahydrobiopterin biosynthesis, regeneration and functions. Biochem J 347 : 1-16, 2000. https://doi.org/10.1042/bj3470001

TILLINGER A, SOLLAS A, SEROVA LI, KVETNANSKY R, SABBAN EL: Vesicular monoamine transporters (VMATs) in adrenal chromaffin cells: stress-triggered induction of VMAT2 and expression in epinephrine synthesizing cells. Cell Mol Neurobiol 30: 1459-1465, 2010. https://doi.org/10.1007/s10571-010-9575-z

TIPTON CM, STUREK MS, OPPLIGER RA, MATTHES RD, OVERTON JM, EDWARDS JG: Responses of SHR to combinations of chemical sympathectomy, adrenal demedullation, and training. Am J Physiol 247: H109-H118, 1984. https://doi.org/10.1152/ajpheart.1984.247.1.H109

TSUNODA M, IMAI K: An assay for determination of rat adrenal catechol-O-methyltransferase activity: comparison of spontaneously hypertensive rats and Wistar-Kyoto rats. Anal Bioanal Chem 380: 887-890, 2004. https://doi.org/10.1007/s00216-004-2884-7

ULRICH-LAI YM, FIGUEIREDO HF, OSTRANDER MM, CHOI DC, ENGELAND WC, HERMAN JP: Chronic stress induces adrenal hyperplasia and hypertrophy in a subregion-specific manner. Am J Physiol Endocrinol Metab 291: E965-E973, 2006. https://doi.org/10.1152/ajpendo.00070.2006

UNGER T, BECKER H, DIETZ R, GANTEN D, LANG RE, RETTIG R, SCHÖMIG A, SCHWAB NA: Antihypertensive effect of the GABA receptor agonist muscimol in spontaneously hypertensive rats. Role of the sympathoadrenal axis. Circ Res 54: 30-37, 1984. https://doi.org/10.1161/01.RES.54.1.30

URBAN R, SZABO B, STARKE K: Involvement of alpha 2-adrenoceptors in the cardiovascular effects of moxonidine. Eur J Pharmacol 282: 19-28, 1995. https://doi.org/10.1016/0014-2999(95)00297-X

VAVŘÍNOVÁ A, BEHULIAK M, BENCZE M, VANĚČKOVÁ I, ZICHA J: Which sympathoadrenal abnormalities of adult spontaneously hypertensive rats can be traced to a prehypertensive stage? Hypertens Res 42: 949-959, 2019a. https://doi.org/10.1038/s41440-018-0198-y

VAVŘÍNOVÁ A, BEHULIAK M, BENCZE M, VODIČKA M, ERGANG P, VANĚČKOVÁ I, ZICHA J: Sympathectomyinduced blood pressure reduction in adult normotensive and hypertensive rats is counteracted by enhanced cardiovascular sensitivity to vasoconstrictors. Hypertens Res 42: 1872-1882, 2019b. https://doi.org/10.1038/s41440$\underline{019-0319-2}$ 
VAVŘÍNOVÁ A, BEHULIAK M, ZICHA J: The importance of the selection of appropriate reference genes for gene expression profiling in adrenal medulla or sympathetic ganglia of spontaneously hypertensive rat. Physiol Res 65: 401-411, 2016. https://doi.org/10.33549/physiolres.933351

VISKUPIC E, KVETNANSKY R, SABBAN EL, FUKUHARA K, WEISE VK, KOPIN IJ, SCHWARTZ JP: Increase in rat adrenal phenylethanolamine N-methyltransferase mRNA level caused by immobilization stress depends on intact pituitary-adrenocortical axis. J Neurochem 63: 808-814, 1994. https://doi.org/10.1046/j.14714159.1994.63030808.x

VLACHAKIS ND, ALEXANDER N, MARONDE RF: Increased plasma normetanephrine in spontaneously hypertensive rats. Clin Exp Hypertens 2: 309-319, 1980. https://doi.org/10.3109/10641968009046426

VOLLMER RR, BARUCHIN A, KOLIBAL-PEGHER SS, COREY SP, STRICKER EM, KAPLAN BB: Selective activation of norepinephrine- and epinephrine-secreting chromaffin cells in rat adrenal medulla. Am J Physiol 263: R716-R721, 1992. https://doi.org/10.1152/ajpregu.1992.263.3.R716

WAKADE AR, WAKADE TD: Absence of catecholamine uptake mechanism in the isolated perfused adrenal gland of the rat. Neurosci Lett 50: 139-143, 1984. https://doi.org/10.1016/0304-3940(84)90476-2

WANG Q, WANG M, WHIM MD: Neuropeptide y gates a stress-induced, long-lasting plasticity in the sympathetic nervous system. J Neurosci 33: 12705-12717, 2013. https://doi.org/10.1523/JNEUROSCI.3132-12.2013

WESTFALl TC, HAN SP, KNUEPFER M, MARTIN J, CHEN XL, DEL VALLE K, CIARLEGLIO A, NAES L: Neuropeptides in hypertension: role of neuropeptide $\mathrm{Y}$ and calcitonin gene related peptide. Br $\mathrm{J}$ Clin Pharmacol 30 (Suppl 1): 75S-82S, 1990. https://doi.org/10.1111/j.1365-2125.1990.tb05472.x

WHALL CW JR, MYERS MM, HALPERN W: Norepinephrine sensitivity, tension development and neuronal uptake in resistance arteries from spontaneously hypertensive and normotensive rats. Blood Vessels 17: 1-15, 1980. https://doi.org/10.1159/000158230

WONG DL: Epinephrine biosynthesis: hormonal and neural control during stress. Cell Mol Neurobiol 26: 891-900, 2006. https://doi.org/10.1007/s10571-006-9056-6

WONG DL: Why is the adrenal adrenergic? Endocr Pathol 14: 25-36, 2003. https://doi.org/10.1385/EP:14:1:25

WONG DL, YAMASAKI L, CIARANELLO RD: Characterization of the isozymes of bovine adrenal medullary phenylethanolamine N-methyltransferase. Brain Res 410: 32-44, 1987. https://doi.org/10.1016/S0006$\underline{\text { 8993(87)80017-3 }}$

YAGIL Y, YAGIL C: Genetic models of hypertension in experimental animals. Exp Nephrol 9: 1-9, 2001. https://doi.org/10.1159/000020701

YAMORI Y, YAMABE H, DE JONG W, LOVENBERG W, SJOERDSMA A: Effect of tissue norepinephrine depletion by 6-hydroxydopamine on blood pressure in spontaneously hypertensive rats. Eur J Pharmacol 17: 135-140, 1972. https://doi.org/10.1016/0014-2999(72)90279-8

ZAGON A, SMITH AD: Monosynaptic projections from the rostral ventrolateral medulla oblongata to identified sympathetic preganglionic neurons. Neuroscience 54: 729-743, 1993. https://doi.org/10.1016/0306-4522(93)90243-9

ZHANG K, CHEN Y, WEN G, MAHATA M, RAO F, FUNG MM, VAINGANKAR S, BISWAS N, GAYEN JR, FRIESE RS, MAHATA SK, HAMILTON BA, O'CONNOR DT: Catecholamine storage vesicles: role of core protein genetic polymorphisms in hypertension. Curr Hypertens Rep 13: 36-45, 2011. https://doi.org/10.1007/s11906-010$\underline{0170-\mathrm{y}}$

ZHANG W, THORÉN P: Hyper-responsiveness of adrenal sympathetic nerve activity in spontaneously hypertensive rats to ganglionic blockade, mental stress and neuronglucopenia. Pflugers Arch 437: 56-60, 1998. https://doi.org/10.1007/s004240050746

ZICHA J, KUNES J: Ontogenetic aspects of hypertension development: analysis in the rat. Physiol Rev 79: 1227-1282, 1999. https://doi.org/10.1152/physrev.1999.79.4.1227 